medRxiv preprint doi: https://doi.org/10.1101/2021.06.28.21259398; this version posted January $12,2022$. The copyright holder for this preprint (which was not certified by peer review) is the author/funder, who has granted medRxiv a license to display the preprint in It is made available under a CC-BY-NC-ND 4.0 International license .

\title{
RT-LAMP has high accuracy for detecting SARS-CoV-2 in saliva and naso/oropharyngeal swabs from asymptomatic and symptomatic individuals
}

Short title: RT-LAMP for detecting SARS-CoV-2 in saliva and naso/oropharyngeal swabs

tStephen P. Kidd ${ }^{1,2}$, †Daniel Burns ${ }^{1,3}$, Bryony Armson ${ }^{1,2,4}$, Andrew D. Beggs ${ }^{5}$, Emma L. A. Howson ${ }^{6}$, Anthony Williams $^{7}$, Gemma Snell 7 , Emma L. Wise ${ }^{1,8}$, Alice Goring ${ }^{1}$, Zoe Vincent-Mistiaen ${ }^{9}$, Seden Grippon ${ }^{1}$, Jason Sawyer ${ }^{10}$, Claire Cassar ${ }^{10}$, David Cross ${ }^{10}$, Thomas Lewis ${ }^{10}$, Scott M. Reid ${ }^{10}$, Samantha Rivers ${ }^{10}$, Joe James ${ }^{10}$, Paul Skinner ${ }^{10}$, Ashley Banyard ${ }^{10}$, Kerrie Davies ${ }^{11}$, Anetta Ptasinska ${ }^{5}$, Celina Whalley ${ }^{5}$, Jack Ferguson ${ }^{5}$, Claire Bryer ${ }^{5}$, Charlie Poxon ${ }^{5}$, Andrew Bosworth ${ }^{5}$, Michael Kidd ${ }^{5,12}$, Alex Richter ${ }^{13}$, Jane Burton ${ }^{14}$, Hannah Love $^{14}$, Sarah Fouch ${ }^{1}$, Claire Tillyer ${ }^{1}$, Amy Sowood ${ }^{1}$, Helen Patrick ${ }^{1}$, Nathan Moore ${ }^{1}$, ${ }^{\pi}$ Michael Andreou ${ }^{15}$, ${ }^{\pi}$ Nick Morant ${ }^{16}$, Rebecca Houghton ${ }^{1}$, Joe Parker ${ }^{17}$, Joanne Slater-Jefferies ${ }^{17}$, lan Brown ${ }^{10}$, Cosima Gretton ${ }^{2}$, Zandra Deans ${ }^{2}$, Deborah Porter ${ }^{2}$, Nicholas J. Cortes ${ }^{1,9}$, Angela Douglas², Sue L. Hill², *Keith M. Godfrey ${ }^{18,19}$, +Veronica L. Fowler ${ }^{1,2}$

${ }^{1}$ Hampshire Hospitals NHS Foundation Trust, Department of Microbiology, Basingstoke and North Hants Hospital, Basingstoke, UK

${ }^{2}$ NHS Test and Trace Programme, Department of Health and Social Care, UK

${ }^{3}$ School of Electronics and Computer Science, University of Southampton, UK

${ }^{4}$ vHive, School of Veterinary Medicine, University of Surrey, Guildford, UK

${ }^{5}$ University Hospitals Birmingham NHS Foundation Trust, Birmingham, UK

${ }^{6}$ The Pirbright Institute, Ash Road, Pirbright, Woking, UK

${ }^{7}$ University of Southampton \& Division of Specialist Medicine, University Hospital Southampton, UK

${ }^{8}$ School of Biosciences and Medicine, University of Surrey, Guildford, UK

${ }^{9}$ Gibraltar Health Authority, Gibraltar, UK

${ }^{10}$ Animal and Plant Health Agency, New Haw, Addlestone, Surrey, UK

${ }^{11}$ Leeds Teaching Hospitals NHS Trust and University of Leeds, UK

${ }^{12}$ Public Health West Midlands Laboratory, Birmingham, UK

${ }^{13}$ Institute of Immunology and Immunotherapy, University of Birmingham, UK

${ }^{14}$ High Containment Microbiology, National Infection Service, Public Health England, Porton Down, UK

${ }^{15}$ OptiSense Limited, Horsham, West Sussex, UK

${ }^{16}$ GeneSys Biotech Limited, Camberley, Surrey, UK

${ }^{17}$ National Biofilms Innovation Centre, University of Southampton, UK

${ }^{18}$ NIHR Southampton Biomedical Research Centre, University of Southampton and University Hospital, UK

${ }^{19} \mathrm{MRC}$ Lifecourse Epidemiology Centre, University of Southampton, UK

†Denotes co-first authorship; +Senior author; *Corresponding author

${ }^{\pi}$ Supplied reagents free of charge but did not assist in study design or data analysis.

Corresponding author: Keith M. Godfrey, kmg@soton.ac.uk, MRC Lifecourse Epidemiology Centre (University of Southampton), University Hospital Southampton, Mailpoint 95, Southampton SO16 6YD, UK.

Tables: 5, Figures: 4

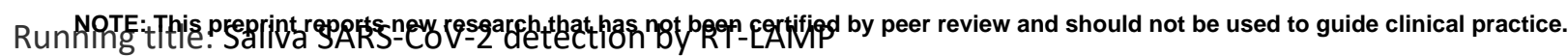


medRxiv preprint doi: https://doi.org/10.1101/2021.06.28.21259398; this version posted January 12, 2022. The copyright holder for this preprint (which was not certified by peer review) is the author/funder, who has granted medRxiv a license to display the preprint in It is made available under a CC-BY-NC-ND 4.0 International license .

42 Grant numbers and sources of support: OptiGene Ltd. suppled reagents free of charge for this study. This 43 work was partially funded by a UK Department of Health and Social Care award to the University of 44 Southampton (Grant Reference Number 2020/032 (Feasibility study for city-wide testing using saliva 315 45 based LAMP testing)). The views expressed are those of the authors and not necessarily those of the 46 Department of Health and Social Care. KMG is supported by the UK Medical Research Council 47 (MC_UU_12011/4), the National Institute for Health Research (NIHR Senior Investigator (NF-SI-0515- 318 48 10042) and NIHR Southampton Biomedical Research Centre (IS-BRC-1215-20004)) and the British Heart 49 Foundation (RG/15/17/3174). For part of this project, Emma Howson was on secondment at GeneSys 50 Biotech Ltd., which was part funded by The Pirbright Institute Flexible Talent Mobility Account (FTMA) 51 under BBSRC grant BB/S507945/1. ADB is currently supported by a Cancer Research UK Advanced 52 Clinician Scientist award (C31641/A23923) and his laboratory is supported by CRUK Centre Birmingham 53 (C17422/A25154) and the Birmingham Experimental Cancer Medicine Centre (C11497/A25127). VLF, SPK, 54 BA and ZD were on secondment to the Department of Health and Social Care for a period during this 55 study. APHA laboratory activities and expertise was supported by both the Safe and Certain project 56 APHACSKL0085 and Defra project APHANSOM0416.

57 Disclosures: MA is an employee of OptiSense Limited, and NM an employee of GeneSys Biotech Limited; 58 neither had any role in study design or data analysis. KMG is part of an academic consortium that has 59 received research funding from Abbott Nutrition, Nestec, BenevolentAI Bio Ltd. and Danone. 
medRxiv preprint doi: https://doi.org/10.1101/2021.06.28.21259398; this version posted January 12, 2022. The copyright holder for this preprint (which was not certified by peer review) is the author/funder, who has granted medRxiv a license to display the preprint in It is made available under a CC-BY-NC-ND 4.0 International license .

62

63

64

65

66

67

68

69

70

71

72

73

74

75

76

77

78

79

80

\section{Abstract}

Previous studies have described RT-LAMP methodology for the rapid detection of SARS-CoV-2 in nasopharyngeal (NP) and oropharyngeal (OP) swab and saliva samples. This study describes the validation of an improved sample preparation method for extraction free RT-LAMP and defines the clinical performance of four different RT-LAMP assay formats for detection of SARS-CoV-2 within a multisite clinical evaluation. Direct RT-LAMP was performed on 559 swabs and 86,760 saliva samples and RNA RTLAMP on extracted RNA from 12,619 swabs and 12,521 saliva from asymptomatic and symptomatic individuals across healthcare and community settings. For Direct RT-LAMP, overall diagnostic sensitivity (DSe) of 70.35\% (95\% Cl 63.48-76.60\%) on swabs and 84.62\% (79.50-88.88\%) on saliva was observed, with diagnostic specificity (DSp) of 100\% (98.98-100.00\%) on swabs and 100\% (99.72-100.00\%) on saliva when compared to RT-qPCR; analysing samples with RT-qPCR ORF1ab $C_{T}$ values of $\leq 25$ and $\leq 33$, DSe of $100 \%$ (96.34-100\%) and $77.78 \%$ (70.99-83.62\%) for swabs were observed, and 99.01\% (94.61-99.97\%) and 87.61\% (82.69-91.54\%) for saliva, respectively. For RNA RT-LAMP, overall DSe and DSp were 96.06\% (92.88-98.12\%) and 99.99\% (99.95-100\%) for swabs, and 80.65\% (73.54-86.54\%) and 99.99\% (99.95$100 \%)$ for saliva, respectively. These findings demonstrate that RT-LAMP is applicable to a variety of usecases, including frequent, interval-based testing of saliva with Direct RT-LAMP from asymptomatic individuals that may otherwise be missed using symptomatic testing alone. 
medRxiv preprint doi: https://doi.org/10.1101/2021.06.28.21259398; this version posted January $12,2022$. The copyright holder for this preprint (which was not certified by peer review) is the author/funder, who has granted medRxiv a license to display the preprint in It is made available under a CC-BY-NC-ND 4.0 International license.

\section{Introduction}

Rapid diagnostic testing to identify and isolate symptomatic and asymptomatic individuals potentially transmitting infectious viral pathogens is an essential requirement of any pandemic response. The novel betacoronavirus, SARS-CoV-2, initially identified after an outbreak of viral pneumonia in Wuhan, China in December $2019^{1}$, has rapidly spread throughout the world, causing over 223 million confirmed cases and over 4.6 million deaths (https://coronavirus.jhu.edu/ - September 10, 2021).

Conventional diagnostics for SARS-CoV-2 consist of RNA enrichment followed by reverse-transcriptase quantitative real-time PCR (RT-qPCR) against one or more viral gene targets ${ }^{2}$. However, this methodology requires sample inactivation, RNA extraction and RT-qPCR thermal cycling, meaning that the time from sample-to-result can often be several hours, and requires centralised equipment and personnel trained in Good Laboratory Practice to perform testing.

The utility of reverse-transcriptase loop mediated isothermal amplification (RT-LAMP) for the detection of SARS-CoV-2 both from extracted RNA (RNA RT-LAMP) and directly from NP/OP swabs (Direct RTLAMP) $^{3}$ has previously been shown. RT-LAMP utilises a rapid and stable DNA polymerase that amplifies target nucleic acids at a constant temperature. This removes the requirement for conventional thermal cycling allowing RT-LAMP reactions to be performed in shorter reaction times using less sophisticated platforms.

In a study of 196 clinical samples ${ }^{3}$, testing of RNA extracted from NP/OP swabs collected into viral transport media (VTM) using RNA RT-LAMP demonstrated a diagnostic sensitivity (DSe) of $97 \%$ and a diagnostic specificity (DSp) of 99\% in comparison to RT-qPCR of the ORF1ab region of SARS-CoV-2. For Direct RT-LAMP on crude swab samples, the DSe and DSp were $67 \%$ and $97 \%$, respectively. When a cycle threshold $\left(\mathrm{C}_{\mathrm{T}}\right)$ cut-off for RT-qPCR of $<25$ was considered, reflecting the increased likelihood of detecting viral RNA from active viral replication, the DSe of Direct RT-LAMP increased to $100 \%^{3}$.

However, the collection of a swab sample is invasive and during the time of the pandemic there have been considerable shortages in swab supplies. Exploring the use of alternative sample types that are both easy to collect and more comfortable from a sampling perspective ${ }^{4,5,6}$ is desirable particularly when repeat sampling is performed ${ }^{7,8,9}$. Saliva presents an ideal bio-fluid that fulfils both these objectives and previous studies have shown that SARS-CoV-2 is readily detectable in such a sample type $\mathrm{e}^{10,11,12-18}$. To improve the diagnostic sensitivity of previously described saliva Direct RT-LAMP ${ }^{3}$, optimisation of saliva preparation for the detection of SARS-CoV-2 was undertaken utilising a cohort of 3100 saliva samples from an asymptomatic population ${ }^{19}$ of healthcare workers; where saliva was diluted 1:1 in Mucolyse ${ }^{\mathrm{TM}}$, followed by a 1 in 10 dilution in $10 \%(w / v)$ Chelex ${ }^{\odot} 100$ Resin ending with a $98^{\circ} \mathrm{C}$ heat step prior to RTLAMP which resulted in optimal sensitivity and specificity. 
medRxiv preprint doi: https://doi.org/10.1101/2021.06.28.21259398; this version posted January $12,2022$. The copyright holder for this preprint (which was not certified by peer review) is the author/funder, who has granted medRxiv a license to display the preprint in It is made available under a CC-BY-NC-ND 4.0 International license .

Despite the benefits of this optimisation, the protocol added additional steps and reagents which increased chance for user error and made the automation of the process more challenging. This study therefore aimed to investigate a simpler process using a novel reagent, Rapilyze (OptiGene Ltd, Camberley, UK), which is a sample dilution buffer, followed by a two-minute heat-step. This novel sample preparation method was evaluated in combination with Direct RT-LAMP using samples collected from symptomatic National Health Service (NHS) patients and symptomatic and asymptomatic healthcare staff.

\section{Methods}

\section{Ethical statement}

All relevant ethical guidelines have been followed, and any necessary IRB and/or ethics committee approvals have been obtained. National Research Ethics Service Committee West Midlands - South Birmingham 2002/201 Amendment Number 4. All necessary written participant consent has been obtained and the appropriate institutional forms have been archived.

\section{Testing sites}

The OptiGene Ltd. SARS-CoV-2 RT-LAMP assay was evaluated in nine sites, comprising Basingstoke and North Hampshire Hospital \& Royal Hampshire County Hospital, Hampshire Hospitals NHS Foundation Trust; University Hospital Southampton; Animal and Plant Health Agency/MRC Lifecourse Epidemiology Unit (University of Southampton); Public Health Lab Manchester/CMFT; Leeds Teaching Hospitals NHS Trust; University Hospitals Birmingham (UHB) NHS Foundation Trust/Institute of Cancer \& Genomic Science University of Birmingham; High Containment Microbiology, National Infection Service, Public Health England, Porton Down and Public Health University Laboratory, Gibraltar Health Authority, Gibraltar, UK.

\section{Clinical samples}

Nasopharyngeal (NP) and oropharyngeal (OP) swabs were collected from asymptomatic and symptomatic individuals and placed in viral transport media (VTM).

Drooled saliva samples were collected at the start of the day; prior to eating, drinking, teeth brushing, or using a mouthwash. Saliva was transferred into the specimen pot directly or via a clean teaspoon, according to a standardised protocol. Samples from UHB deposited saliva straight into the collection pot.

\section{Log reduction of SARS-CoV-2 for the heat and lysis steps used independently and sequentially}

We determined the viral inactivation kinetics of the best sample preparation condition(s), evaluating the effect of the heat and lysis steps on the viral inactivation of SARS-CoV-2 as determined by infectivity assays. All inactivation experiments were conducted under Containment Level 3 Containment and as such 
medRxiv preprint doi: https://doi.org/10.1101/2021.06.28.21259398; this version posted January $12,2022$. The copyright holder for this preprint (which was not certified by peer review) is the author/funder, who has granted medRxiv a license to display the preprint in It is made available under a CC-BY-NC-ND 4.0 International license .

were undertaken at APHA. Heat inactivation experiments were conducted utilising high titre live SARSCoV-2 virus spiked into pools of saliva collected from APHA staff or in tissue culture supernatant (TCSN). Early experiments demonstrated that saliva had a high toxicity for tissue culture cells, even after heat inactivation demonstrating that toxicity was likely not enzymatic. As such further inactivation was undertaken on live virus TSCN. Comparison was also undertaken of Betapropiolactone (BPL) inactivated virus and live virus.

\section{RNA extraction}

RNA was extracted using a range of different methods available at each participating site:

Maxwell ${ }^{\circledR}$ RSC Viral Total Nucleic Acid Purification Kit

In a class 1 microbiological safety cabinet (MSC) within a containment level 3 laboratory, $200 \mu$ of sample was added to $223 \mu$ l of prepared lysis solution (including $5 \mu$ l per reaction of Genesig ${ }^{\circledR}$ Easy RNA Internal extraction control, Primerdesign Ltd, Chandler's Ford, UK). Samples were then inactivated for 10 minutes at room temperature within the MSC and 10 minutes at $56^{\circ} \mathrm{C}$ on a heat block before automated RNA extraction using a Maxwell ${ }^{\circledR}$ RSC48 Instrument (Promega UK Ltd., Southampton, UK). RNA was eluted in $50 \mu$ l of nuclease-free water (NFW).

\section{MagMAX ${ }^{\mathrm{IM}}$ CORE Nucleic acid 140 purification kit}

$10 \mu \mathrm{l}$ of sample (diluted in $190 \mu \mathrm{l}$ DEPC treated water) was added to $700 \mu \mathrm{l}$ of prepared lysis solution. Samples were then inactivated for 10 minutes at room temperature within the safety cabinet before automated RNA extraction using a Kingfisher Flex (Thermo Fisher, Basingstoke, UK). RNA was eluted in 90 $\mu \mathrm{l}$ of NFW.

\section{Roche FLOW system}

RNA extraction was carried out on a MagNA Pure 96 (MP96) extraction robot using the MagNA Pure 96 DNA and Viral Nucleic Acid Small Volume kit (Roche, Basel, Switzerland) and the Pathogen 200 universal protocol v4.0.

\section{Qiagen QIAsymphony}

RNA extraction was carried out using the QIASymphony Virus/Bacteria Mini Kit (Qiagen, Hilden, Germany) by the CellFree200 Default IC protocol with a $60 \mu$ l extract elution volume.

\section{SARS-CoV-2 Real-Time RT-qPCR}

RNA was analysed using a range of different methods available at each site: 
medRxiv preprint doi: https://doi.org/10.1101/2021.06.28.21259398; this version posted January $12,2022$. The copyright holder for this preprint (which was not certified by peer review) is the author/funder, who has granted medRxiv a license to display the preprint in It is made available under a CC-BY-NC-ND 4.0 International license .

Single step RT-qPCR against the ORF1ab region and N1 gene target of SARS-CoV-2 was carried out using the CerTest VIASURE SARS-CoV-2 real time PCR kit (CerTest Biotech SL, Zaragoza, Spain) according to manufacturer's instructions for use (IFU) on either the Thermo Fisher QuantStudio 5 or BioMolecular Systems (Queensland, Australia) MIC instruments, using $5 \mu$ l of extracted RNA per reaction. RNA extracted using the Maxwell ${ }^{\circledR}$ RSC Viral Total Nucleic Acid Purification Kit was analysed using this assay.

\section{COVID-19 genesig $^{\circledR}$ Real-Time qPCR assay}

Single step RT-qPCR against the ORF1ab region of SARS-CoV-2 was carried out using the COVID-19 genesig $^{\circledR}$ Real-Time PCR assay real time PCR assay (Primerdesign Ltd, Chandler's Ford, UK) according to manufacturer's instructions for use (IFU) on BioMolecular Systems MIC instruments, using $5 \mu$ l of extracted RNA per reaction. RNA extracted using the Maxwell ${ }^{\circledR}$ RSC Viral Total Nucleic Acid Purification Kit was analysed using this assay.

\section{Corman et al. Real-Time qPCR assay}

Single step RT-qPCR against the $E$ gene target of SARS-CoV-2 was carried out with the Corman et al. ${ }^{2}$ primers using the AgPath-ID ${ }^{\mathrm{TM}}$ PCR kit (Thermo Fisher) according to manufacturer's instructions for use (IFU) on an Aria qPCR Cycler (Agilent, Cheadle, UK) and results analysed using the Agilent AriaMX 1.5 software, using $5 \mu$ l of extracted RNA per reaction. RNA extracted using the MagMAX ${ }^{\mathrm{TM}}$ CORE Nucleic acid purification kit were analysed using this assay.

RT-qPCR was carried out on an Applied Biosystems Fast 7500 PCR thermocycler in standard run mode using the SARS-CoV-2 E gene Sarbeco assay using MS2 as an internal extraction control and aliquots of SARS-CoV-2/England/2/2020 as a positive control. The master mix comprised $E$-gene $\mathrm{F}$ and $\mathrm{R}$ primers and TM-P (400 nM, $400 \mathrm{nM}$ and $200 \mathrm{nM}$ final concentration respectively), MS2 primers and TM probe (20 nM, $20 \mathrm{nM}$ and $40 \mathrm{nM}$ final concentration respectively), 4 x TaqMan $^{\circledR}$ Fast Virus 1-Step Master Mix made up with molecular-grade nuclease free water (Ambion) to a final volume of $15 \mu \mathrm{l} .5 \mu \mathrm{l}$ of AVE buffer extract was used at a template and added to the $15 \mu \mathrm{l}$ mastermix. Cycling conditions were $55^{\circ} \mathrm{C}$ for $10 \mathrm{~min}$, followed by $94^{\circ} \mathrm{C}$ for $3 \mathrm{~min}$ and 45 cycles of $95^{\circ} \mathrm{C}$ for $15 \mathrm{~s}$ and $58^{\circ} \mathrm{C}$ for $30 \mathrm{~s}$.

\section{SARS-CoV-2 (2019-nCoV) CDC qPCR Probe Assay}

Single step RT-qPCR against the N1 and N2 gene targets of SARS-CoV-2 was carried out using integrated design technologies kit (IDT; Catalogue number: 10006606) according to manufacturer's instructions for use (IFU) on either a LC480 II or ABI 7500 FAST instrument. RNA extracted on Qiagen QIAsymphony and the Roche FLOW system were analysed using this RT-qPCR assay. 
medRxiv preprint doi: https://doi.org/10.1101/2021.06.28.21259398; this version posted January $12,2022$. The copyright holder for this preprint (which was not certified by peer review) is the author/funder, who has granted medRxiv a license to display the preprint in It is made available under a CC-BY-NC-ND 4.0 International license.

\section{RT-LAMP}

RT-LAMP assays were performed using OptiGene Ltd. COVID-19_RT-LAMP kits, as described previously ${ }^{3}$, with the following modifications. The COVID-19_RNA RT-LAMP KIT-500 kit was used for RNA RT-LAMP and the COVID-19_Direct PLUS RT-LAMP KIT-500 was used for Direct RT-LAMP directly on oropharyngeal/nasopharyngeal swabs or saliva samples. The COVID-19_Direct PLUS RT-LAMP KIT-500 kit also includes a sample preparation buffer, RapiLyze. For RNA RT-LAMP $5 \mu$ of extracted RNA was added to the reaction. For the Direct PLUS RT-LAMP, $50 \mu \mathrm{l}$ sample (swab VTM or neat saliva) was added to $50 \mu \mathrm{l}$ RapiLyze, vortexed and placed in a dry heat block pre-heated to $98^{\circ} \mathrm{C}$ for 2 mins. $5 \mu$ l of the treated sample was added to each reaction.

The anneal temperature $(\mathrm{Ta})$ that confirmed a positive result for Direct RT-LAMP was modified to $81.5^{\circ} \mathrm{C}$ and $85.99^{\circ} \mathrm{C}$ because of the effect of RapiLyze buffer on the reaction.

\section{SARS-CoV-2 viral culture of clinical samples across a $C_{T}$ range}

For culture, $100 \mu \mathrm{l}$ and $100 \mu \mathrm{l}$ of a 1 in 10 dilution of samples 1-6 (predicted lower $C_{T}$ values) and $100 \mu \mathrm{l}$ samples 7-26 (with higher predicted $C_{T}$ values) were added to a $25 \mathrm{~cm}^{2}$ flasks containing $80 \%$ confluent Vero E6 cells and allowed to adsorb for 1 hour. Five ml of Minimum Essential Medium (MEM) (Gibco) + HEPES (Gibco, Thermo Fisher, Basingstoke, UK) $+4 \%$ foetal calf serum FCS (Sigma) $+1 \times$ antibioticantimycotic (Gibco) was added to each flask and incubated for 1 week at $37^{\circ} \mathrm{C}$. Two negative control flasks to which $100 \mu \mathrm{l}$ MEM + 4\% FCS was added in place of sample, were set up in parallel. Cultures were checked visually for cytopathic effect (CPE). Where CPE was not observed after 1 week, $500 \mu$ of supernatant was passed into a fresh flask containing Vero E6 cells for a further two passages. At the beginning and end of each passage $140 \mu \mathrm{l}$ of supernatant was collected for SARS-CoV-2 RT-qPCR as described before.

To determine the sensitivity of the isolation method for SARS-CoV-2 from clinical samples, a virus stock titred by plaque assay (HCM/V/53), a passage 3 working bank grown from SARS-CoV-2 Strain England 2, from Public Health England, was diluted in MEM to give virus dilutions containing 1000, 100, 10, 1, 0.1 and $0.01 \mathrm{PFU}$. The virus was added to duplicate flasks containing Vero E6 cells and AVL. After 72 hours of incubation flasks were checked for CPE, and for those where CPE was observed the supernatant was collected for RT-qPCR. Any flasks not showing CPE after 7 days were passed on to fresh cells and resampled as described above. 
medRxiv preprint doi: https://doi.org/10.1101/2021.06.28.21259398; this version posted January $12,2022$. The copyright holder for this preprint (which was not certified by peer review) is the author/funder, who has granted medRxiv a license to display the preprint in It is made available under a CC-BY-NC-ND 4.0 International license.

\section{Data analysis}

Overall diagnostic sensitivity and specificity (including 95\% Clopper-Pearson confidence intervals) were calculated by the aggregation of individual site data for each method (RNA and Direct RT-LAMP) for each sample type (swabs and saliva). To demonstrate the effectiveness of detecting samples with higher viral load, confusion matrices are quoted where the threshold for positive sample inclusion varies, i.e., for $\mathrm{C}_{\mathrm{T}}$ $\leq 25$, only positive samples with $\mathrm{C}_{\mathrm{T}} \leq 25$ are included.

To account for site heterogeneity, a bivariate meta-analysis model is additionally applied at the site level to produce a summary of sensitivity and specificity for each method and sample type ${ }^{20}$. Within-study variability for sensitivity $\rho_{s e, i}$ and specificity $\rho_{s e, i}$ are assumed to follow independent binomial distributions

$$
x_{s e, i} \sim B\left(n_{s e, i}, \rho_{s e, i}\right), \quad x_{s p, i} \sim B\left(n_{s p, i}, \rho_{s p, i}\right)
$$

where $x_{s e, i}, x_{s p, i}$ represent the number testing positive for site $i$ respectively, and $n_{s e, i}, n_{s p, i}$ represent the number testing positive and negative by RT-qPCR for site $i$ respectively. The between-study heterogeneity is represented by a bivariate normal distribution for the logit-transformed sensitivity $\mu_{s e, i}$ and specificity $\mu_{s p, i}$

$$
\left(\begin{array}{l}
\mu_{s e, i} \\
\mu_{s p, i}
\end{array}\right) \sim N\left(\left(\begin{array}{l}
\mu_{s e} \\
\mu_{s p}
\end{array}\right),\left(\begin{array}{cc}
\sigma_{s e}^{2} & \sigma_{s e, s p} \\
\sigma_{s e, s p} & \sigma_{s p}^{2}
\end{array}\right)\right)
$$

where $\mu_{s e}, \mu_{s p}$ represent the expected logit sensitivity and specificity, $\sigma_{s e}^{2}, \sigma_{s p}^{2}$ represent the betweenstudy variance in the logit sensitivity and specificity, and $\sigma_{s e, s p}$ represents the covariance between the logit sensitivity and specificity. For Direct RT-LAMP, we fit a univariate normal distribution for the logittransformed sensitivity only, due to the absence of false positives across all sites.

In addition, the sensitivity as a function of viral load was assessed for RNA RT-LAMP and Direct RT-LAMP on both swab and saliva samples. This was performed through the conversion of each sample $C_{T}$ value to viral load in gene copies/ml for all sample sets. As the relationship between $C_{T}$ value and viral load varied according to the RT-qPCR method used; a dilution series was utilised for each method to standardise these values for two of the four aforementioned RT-qPCR methods (CerTest VIASURE SARS-CoV-2 real time PCR kit, and Corman et al RT-qPCR assay E gene), which was used for testing $100 \%$ of the swab samples, $90 \%$ of the saliva samples used for Direct RT-LAMP, and $83 \%$ of the saliva samples used for RNA RT-LAMP. The logarithm of the viral load was then fitted to the $C_{T}$ values for both methods using linear regression followed by converting the $C_{T}$ values to viral load based on which method had been used to evaluate the samples. For the remaining samples $(n=56)$ that utilised one of the other two RT-qPCR methods for which viral load was not standardised against a $C_{T}$ value, the conversion derived from the 
medRxiv preprint doi: https://doi.org/10.1101/2021.06.28.21259398; this version posted January $12,2022$. The copyright holder for this preprint (which was not certified by peer review) is the author/funder, who has granted medRxiv a license to display the preprint in It is made available under a CC-BY-NC-ND 4.0 International license .

267 CerTest VIASURE SARS-CoV-2 real time PCR kit dilution series was applied, the assumption that the $N$ gene

$268 \mathrm{C}_{\mathrm{T}}$ values are the most similar ${ }^{21-23}$.

269 For the CerTest VIASURE SARS-CoV-2 real time PCR kit, the following relationship between log viral load 270 and $\mathrm{C}_{\mathrm{T}}$ value was applied:

$$
\log _{10} V=\left(45.257-C_{T}\right) / 3.523
$$

and similarly, for the Corman et al RT-qPCR assay:

$$
\log _{10} V=\left(45.806-C_{T}\right) / 3.717
$$

274 where $V$ represents the viral load in copies $/ \mathrm{ml}$.

275 Viral load was grouped according to the following categories (in copies/ml): $<10^{3}, 10^{3}-10^{4}, 10^{4}-10^{5}, 10^{5}$ $27610^{6}, 10^{6}-10^{7}$ and $>10^{7}$ then the diagnostic sensitivity was calculated according to viral load group with 277 associated Clopper-Pearson 95\% confidence intervals.

278 The site meta-analysis was produced using R 3.5.3. Confusion matrices, sensitivity, specificity, sensitivity 279 as a function of viral load calculations, and the production of scatter graphs showing the relationship 280 between RT-LAMP results and $C_{T}$ were performed using Python 3.8.6. 
medRxiv preprint doi: https://doi.org/10.1101/2021.06.28.21259398; this version posted January $12,2022$. The copyright holder for this preprint (which was not certified by peer review) is the author/funder, who has granted medRxiv a license to display the preprint in It is made available under a CC-BY-NC-ND 4.0 International license.

\section{Results}

\section{Optimisation of sample preparation conditions}

Heat inactivation experiments demonstrated that SARS-CoV-2 was completely inactivated by heating at $60^{\circ} \mathrm{C}$ (20 min plus) or $\geq 70^{\circ} \mathrm{C}$ (after 2,5 or $10 \mathrm{~min}$ ) (Supplemental Table S1). Importantly optimised RapiLyze Sample Lysis Buffer did not inactivate live virus on its own without a heat step. Further, inactivation at $56^{\circ} \mathrm{C}$ was not $100 \%$ effective at shorter incubation times, and additionally showed a loss in sensitivity following a $4 \times 2$-fold dilution (Supplemental Table S2, P07102) at 10 and 30 minutes. Following optimisation of heat inactivation of live virus, pre-treatment of samples was assessed to determine any impact of pre-treatment on assay sensitivity. Interestingly, a pre-treatment $70^{\circ} \mathrm{C}$ for 5 mins carried out on spiked samples prior to the proposed direct RT-LAMP assay had no effect on subsequent LAMP or PCR results. It recommended that even if a pre-treatment is effective in inactivating the virus that downstream processes are carried out in UV hoods or with effective air-flow management to prevent cross contamination of the direct RT-LAMP assay. Comparison of Betapropiolactone (BPL) inactivated virus and live virus demonstrated that BPL inactivation has resulted in lower sensitivity of detection using direct RTLAMP. BPL inactivated virus is therefore not an ideal substitute for live virus in spiking experiments. Any conclusions on assay sensitivity or performance have consequently been drawn from experiments on spiking of live virus in TCSN or saliva carried out in containment. Spiking of live virus into pooled saliva has demonstrated that direct detection by RT-LAMP is possible in samples that give a $C_{T}$ below $25 / 26$ with extraction and PCR.

\section{RNA RT-LAMP}

VTM from 12,619 NP/OP swabs were assayed. 265 swab samples were from known symptomatic individuals and 2073 swab samples were from known asymptomatic individuals. The clinical status of the remaining samples $(n=10,281)$ was unknown.

12,521 neat saliva samples were assayed, none of which were from known symptomatic individuals. 12,365 of these samples were from known asymptomatic individuals. The clinical status of the remaining saliva samples $(n=156)$ was unknown.

\section{Direct RT-LAMP}

VTM from 559 NP/OP swabs were assayed. 170 swab samples were from known symptomatic individuals and 310 samples were from known asymptomatic individuals and the clinical status of the remaining swab samples $(n=79)$ was unknown.

86,760 neat saliva samples were assayed. 93 samples were from known symptomatic individuals and 86,593 samples were from known asymptomatic individuals. The clinical status of the remaining samples 
medRxiv preprint doi: https://doi.org/10.1101/2021.06.28.21259398; this version posted January $12,2022$. The copyright holder for this preprint (which was not certified by peer review) is the author/funder, who has granted medRxiv a license to display the preprint in It is made available under a CC-BY-NC-ND 4.0 International license.

314 ( $n=74)$ was unknown. In addition, 10 separate longitudinal daily saliva samples were provided from one

315 individual as a time course from development of symptoms to three days post resolution of symptoms.

316

317

318

319

320

321

322

323

324

325

326

327

328

329

330

331

332

333

334

335

336

337

338

339

340

341

342

343

344

345

346

\section{RNA RT-LAMP on NP/OP swabs}

A total of 12,619 swab samples were assayed by RNA RT-LAMP, of which 254 were RT-qPCR positive and 12,365 were RT-qPCR negative. RNA RT-LAMP detected 244 of the 254 positives (Figure 1 and Table 1). Only one of the 12,365 samples negative by RT-qPCR was positive by RNA RT-LAMP. 588 samples were tested in duplicate and 12,031 were tested as single replicates. Of those samples tested in duplicate seven were detected by RNA RT-LAMP in only a single replicate $\left(C_{T} S 27.00,32.66,33.14,33.16,34.07,35.05\right.$, and 37.20 all of these had received at least one freeze thaw before analysis. Overall diagnostic sensitivity (DSe) was 96.06\% (95\% Cl 92.88-98.12) and specificity (DSp) 99.99\% (95\% Cl 99.95-100.00), which is corrected to DSe 95.98\% (95\% Cl 92.70-97.83) and DSp 99.99\% (95\% Cl 99.94-100.00) after site metaanalysis. Diagnostic sensitivity of samples with a $C_{T} \leq 25(n=123)$ was $100.00 \%(95 \% \mathrm{Cl} 96.76-100.00)$ and specificity 99.99\% (95\% Cl 99.95-100.00), and of samples with a $C_{T} \leq 33$ ( $\left.n=180\right)$ was $98.65 \%$ (95\% Cl 96.1099.72) and specificity 99.99\% (95\% Cl 99.95-100.00).

\section{Direct RT-LAMP on NP/OP swabs}

559 swab samples were assayed by Direct RT-LAMP of which 199 were RT-qPCR positive and 360 were RT-qPCR negative. Direct RT-LAMP detected 140 of the 199 samples positive by RT-qPCR (Figure 1 and Table 2). 195 samples were tested in duplicate and 364 tested as single replicates. Seven of 195 samples tested in duplicate were positive by Direct RT-LAMP in only one replicate $\left(C_{T} 27.51,27.95,28.15,28.15\right.$, $28.87,28.92$, and 28.95 ) all these samples had received at least one freeze thaw before analysis. Overall diagnostic sensitivity was $70.35 \%$ (95\% Cl 63.48-76.60) and specificity $100 \%$ (95\% Cl 98.98-100). After correction by site meta-analysis, the DSe is corrected to $67.59 \%$ (95\% Cl 53.71-78.94). Diagnostic sensitivity of samples with a $C_{T} \leq 25(n=113)$ was $100 \%(95 \% \mathrm{Cl} 96.34-100)$ and specificity $100 \%(95 \% \mathrm{Cl}$ 98.98-100), and of samples with a $C_{T} \leq 33(n=182)$ was $77.78 \%(95 \% \mathrm{Cl} 70.99-83.62)$ and specificity $100 \%$ (95\% Cl 98.98-100).

\section{RNA RT-LAMP on saliva}

Saliva samples numbering 12,521 were assayed by RNA RT-LAMP of which 155 were RT-qPCR positive and 12,366 were RT-qPCR negative. RNA RT-LAMP detected 133 of the 155 samples that were positive by RTqPCR (Figure 1 and Table 3). Only one of the 12,366 samples negative by RT-qPCR was positive by RNA RT-LAMP. 44 samples were tested in duplicate and 12,477 were tested as single replicates. All samples tested in duplicate were positive in both replicates. Overall diagnostic sensitivity was $80.65 \%(95 \% \mathrm{Cl}$ 73.54-86.54) and specificity 99.99\% (95\% Cl 99.95-100), which is corrected to DSe $79.05 \%$ (95\% Cl 68.87 - 86.55) and DSp 99.99\% (95\% Cl 99.74-100) after site meta-analysis. Diagnostic sensitivity of samples 
medRxiv preprint doi: https://doi.org/10.1101/2021.06.28.21259398; this version posted January $12,2022$. The copyright holder for this preprint (which was not certified by peer review) is the author/funder, who has granted medRxiv a license to display the preprint in It is made available under a CC-BY-NC-ND 4.0 International license.

with a $C_{T} \leq 25(n=74)$ was $100 \%$ (95\% Cl 93.73-100) and specificity 99.99\% (95\% Cl 99.95-100), and of samples with a $C_{T} \leq 33(n=150)$ was $87.32 \%(95 \% \mathrm{Cl} 80.71-92.31)$ and specificity $99.95(95 \% \mathrm{Cl} 99.95-$ 100.00).

\section{Direct RT-LAMP on saliva}

86,760 saliva samples were tested by Direct RT-LAMP of which 247 were RT-qPCR positive and 7,195 were RT-qPCR negative (79,318 were negative on RT-LAMP but were not tested by RT-qPCR) (Figure 1 and Table 4). Direct RT-LAMP detected 209 of the 247 samples positive by RT-qPCR. 83 samples were tested in duplicate and 86,677 were tested as single replicates. Nine of the 83 samples tested in duplicate were negative in one of the duplicates and all these samples had received at least one freeze thaw before analysis $\left(C_{T} 20.27,21.28,22.01,24.42,25.85,27.35,28.52\right.$, and 30.37$)$. Overall diagnostic sensitivity was 84.62\% (95\% Cl 79.50-88.88) and specificity $100 \%$ (95\% Cl 99.72-100). After correction by site metaanalysis, DSe is corrected to $84.24 \%$ (95\% $\mathrm{Cl} 55.03-95.89)$. Diagnostic specificity was calculated using only the confirmed RT-qPCR negative samples. Diagnostic sensitivity of samples with a $C_{T} \leq 25$ ( $\left.n=126\right)$ was 99.01\% (95\% Cl 94.61-99.97) and specificity 100.00\% (95\% Cl 99.72-100), and of samples with a $\mathrm{C}_{\mathrm{T}} \leq 33$ $(n=237)$ was $87.61 \%(95 \% \mathrm{Cl} 82.69-91.54)$ and specificity $100 \%(95 \% \mathrm{Cl} 99.72-100)$.

\section{Relationship between cycle threshold $\left(C_{T}\right)$ value and time to positivity (Tp)}

The relationship between $C_{T}$ value and Tp was explored with the results shown in Figure 1. Whilst there is a weak linear relationship between $C_{T}$ value and Tp across all methods and sample types, a stronger linear relationship was observed in swab samples with $R^{2}=0.431$ for RNA RT-LAMP and $R^{2}=0.462$ for Direct RT-LAMP. There was a notably weaker linear relationship in saliva samples $R^{2}=0.201$ for RNA RTLAMP and $R^{2}=0.204$ for Direct RT-LAMP. For RNA RT-LAMP, there was a notable increase in Tp variance, $\sigma_{T p}^{2}$, after $\mathrm{C}_{\mathrm{T}}=20$ across both sample types. On saliva samples, $\sigma_{T p}^{2}=0.81$ for $\mathrm{C}_{\mathrm{T}} \leq 20$, and $\sigma_{T p}^{2}=20.41$ for $\mathrm{C}_{\mathrm{T}}>20$; on swabs samples, $\sigma_{T p}^{2}=1.96$ and $\mathrm{C}_{\mathrm{T}} \leq 20$, and $\sigma_{T p}^{2}=15.72$ for $\mathrm{C}_{\mathrm{T}}>20$. Given the relationship between $C_{T}$ value and viral load, this indicates that $T p$ is not a reliable indicator for viral load beyond the $\mathrm{C}_{\mathrm{T}}=20$ threshold.

\section{SARS-CoV-2 viral culture of clinical samples across a $C_{T}$ range}

Although not a large sample size; a negative result via Direct RT-LAMP indicates that the presence of culturable virus is less probable and for samples with a $C_{T}>25$ (RDRP/ORF1ab target) recoverable virus is less likely (Table 5). The sensitivity of $1 \mathrm{PFU} / \mathrm{ml}$ of the viral culture assay is presented in Supplemental Table S3. No CPE was observed in the flasks inoculated with 0.1 or 0.01 PFU after the two passes. AVL samples were taken from the flasks at the beginning and end of each passage and the $C_{T}$ values of the extracted nucleic acids shown in Supplemental Table S3. 
medRxiv preprint doi: https://doi.org/10.1101/2021.06.28.21259398; this version posted January $12,2022$. The copyright holder for this preprint (which was not certified by peer review) is the author/funder, who has granted medRxiv a license to display the preprint in It is made available under a CC-BY-NC-ND 4.0 International license.

\section{Individual time course}

In the time course experiment SARS-CoV-2 RNA was detected from day 5 (at the onset of symptoms) up to day 12 post suspected initial exposure using Direct RT-LAMP and up to day 13 by RNA RT-LAMP, encompassing the full six days where symptoms were recorded, Supplemental Table S4.

\section{Performance of RT-LAMP across viral load groups}

The sensitivity of the RNA and Direct RT-LAMP assays across viral load groups is shown in Figure 2. For RNA RT-LAMP, samples which were positive by RT-qPCR containing $>10^{5}$ copies $/ \mathrm{ml}$ were consistently identified as positive with no samples returning a negative result. Below this copy number, sensitivity is reduced for both saliva and NP/OP swab samples, reaching 60\% in NP/OP swab samples exclusively with viral loads $<10^{3}$ copies $/ \mathrm{ml}$, and an approximately linear drop in sensitivity from $100 \%$ to $0 \%$ between viral loads of $10^{5}$ and $10^{3}$ copies $/ \mathrm{ml}$ respectively in saliva samples. For Direct RT-LAMP, all but one saliva sample were detected above $10^{6} \mathrm{copies} / \mathrm{ml}$. On swab samples, sensitivity is reduced on samples containing below $<10^{5}$ copies $/ \mathrm{ml}$, dropping from $85 \%$ at viral loads of $10^{5}-10^{6}$ copies $/ \mathrm{ml}$, to $30 \%$ in the $10^{4}-10^{5}$ range. On saliva samples, sensitivity is reduced in the $10^{4}-10^{5}$ range to a sensitivity of $80 \%$ but then reduces further within the $10^{3}-10^{4}$ range, to $30 \%$.

\section{Site meta-analysis}

Site-level confusion matrices, sensitivity, and specificity per method and sample type are shown in Figures 3 and 4 . For specificity, heterogeneity between sites was minimal for all combinations of method and sample type, with the random effects model matching the overall aggregated sample calculation. For sensitivity, heterogeneity was minimal between sites for RNA RT-LAMP. However, for Direct RT-LAMP, sensitivity showed significant overall heterogeneity (bivariate model variance: $\sigma_{s e}^{2}=1.817$ on saliva samples; $\sigma_{s e}^{2}=0.228$ on swab samples). Between-site variations in the viral load of the samples tested contributed a minority of the heterogeneity, but sensitivity was consistently high in samples with higher viral loads (i.e., $>10^{6}$ copies $/ \mathrm{ml}$, as shown in Figure 2 ), while being more heterogeneous between sites in samples with lower viral loads. Sensitivity at lower viral loads was highest in the sites with the most established testing programmes.

\section{Discussion}

Testing of human populations for SARS-CoV-2 nucleic acid has been hampered by both logistical (e.g., swab availability) and physical (e.g., discomfort from repeat swab testing) constraints. The aim of this study was to evaluate an optimised sample preparation method, building upon previously published methods for the extraction-free detection of SARS-CoV-2 by RT-LAMP primarily from saliva ${ }^{3,19}$. The 
medRxiv preprint doi: https://doi.org/10.1101/2021.06.28.21259398; this version posted January $12,2022$. The copyright holder for this preprint (which was not certified by peer review) is the author/funder, who has granted medRxiv a license to display the preprint in It is made available under a CC-BY-NC-ND 4.0 International license .

411 salivary glands are reported to be early targets of SARS-CoV-2 infection, ${ }^{24}$, and studies have demonstrated 412 the detection of high viral loads of SARS-CoV-2 from saliva, similar to those observed from 413 nasopharyngeal/oropharyngeal swabs ${ }^{15,25-27}$. Collection of saliva is non-invasive and does not require a 414 trained individual or specialist consumables for collection of a quality sample. Utilising a non-invasive 415 sampling method should open testing to more individuals who dislike or are unable to tolerate having a 416 nasopharyngeal/oropharyngeal swab taken ${ }^{28}$. Additionally, several studies have demonstrated that SARS417 CoV-2 viral RNA could be detected from saliva for a similar duration post onset of clinical signs when compared to combined NP/OP swabs ${ }^{29-31}$, highlighting saliva as a valuable tool for SARS-CoV-2 detection.

419 Direct detection negates the requirement for RNA extraction ${ }^{32,33}$, for which there has previously been competition for reagents and often requires expensive extraction equipment including liquid handling automation. This extraction-free method decreases turnaround time from sample collection to result.

422 The Direct RT-LAMP method is straight forward and rapid, allowing the test to be performed in a wide 423 range of settings, including near-patient hospital laboratories and pop-up or mobile laboratories. 424 However, previously evaluated extraction-free sample preparation methods using RT-LAMP from saliva samples have demonstrated reduced sensitivity 3,19 , likely due to the inhibitory factors found within saliva that may affect molecular tests such as RT-LAMP and RT-qPCR ${ }^{34,35}$. The simple sample preparation method evaluated in the study aimed to improve upon these methods by utilising the addition of a novel proprietary reagent, Rapilyze ${ }^{\odot}$, designed to neutralize common sample inhibitors. A subsequent heat step of $98^{\circ} \mathrm{C}$ for two minutes prior to addition to the RT-LAMP master mix renders SARS-CoV-2 inactive as confirmed by infectivity analysis using live virus inactivation studies (Supplemental Tables S1 and S2). Downstream steps are then able to proceed outside of traditional containment level laboratory settings broadening its clinical utility.

This study utilised high numbers of combined naso/oropharyngeal swabs $(n=559)$ and saliva samples ( $n$ $=86,760$ ) for the evaluation of this novel sample preparation method in combination with the Direct RTLAMP assay. RNA RT-LAMP was also performed on >25,000 samples for comparison, providing updated values for the performance of the assay reported previously ${ }^{3,19,36}$. Correlation between $C_{T}$ value and sample viral copy number has been demonstrated within this and other studies, with lower $C_{T}$ values $\left(C_{T}\right.$ $<25$ and <33) indicating a higher probability that the sample contains recoverable active virus, and consequently the likelihood that the individual may be infectious to others ${ }^{4,25,37-40}$. As a result, the RNA and Direct RT-LAMP assays were compared with RT-qPCR results in groups with three different $\mathrm{C}_{\mathrm{T}}$ cut-off values: $<45,<33$ and $<25$. This was completed so that the performance of the assays in different clinical scenarios (use case) could be determined: (i) $\mathrm{C}_{\mathrm{T}}<45$ : does the RT-LAMP assay (either RNA or Direct) compare with RT-qPCR for all reportable $C_{T}$ values?; (ii) $C_{T}<33$ : can the RT-LAMP assay detect those individuals that have a medium-high levels of viral RNA in their specimens, with an ORF1ab target being 
medRxiv preprint doi: https://doi.org/10.1101/2021.06.28.21259398; this version posted January $12,2022$. The copyright holder for this preprint (which was not certified by peer review) is the author/funder, who has granted medRxiv a license to display the preprint in It is made available under a CC-BY-NC-ND 4.0 International license .

analogous with viral copy number because it is exclusively a genomic target ${ }^{22}$; and (iii) $\mathrm{C}_{\mathrm{T}}<25$ : can the RTLAMP assay detect those individuals that have a high level of viral RNA in their specimens?

Diagnostic sensitivity for RNA RT-LAMP on swab and saliva samples was improved when compared to a previous report utilising this method ${ }^{3}$, with values of $>96 \%$ and $>80 \%$, respectively when considering all $C_{T}$ values, and $100 \%$ for both sample types when considering $C_{T}<25$ with these samples having a high probability of containing replicating virus for over 24,000 samples tested. Direct RT-LAMP sensitivity on swab samples was also improved from the previous method with $100 \%$ sensitivity for $C_{T}<25,77.78 \%$ for $\mathrm{C}_{\mathrm{T}}<33$ and $70.35 \%$ for $\mathrm{C}_{\mathrm{T}}<45$ across 559 samples used for this evaluation. In contrast, sensitivity for Direct RT-LAMP on saliva was in general higher than that determined for swabs $\left(C_{T}<33=87.61 \%, C_{T}<45=\right.$ $84.62 \%)$, apart from the group with $C_{T}$ values below $<25$, which had a reported sensitivity of $99.01 \%$. These results support previous reports which demonstrate comparable performance when comparing paired swabs and saliva samples ${ }^{41,42}$, and that one sample type is not superior to the other. Interestingly, the diagnostic sensitivity for RNA and Direct RT-LAMP for saliva samples was almost equivalent $(80.65 \%$ and $84.62 \%$, respectively) suggesting that RNA extraction may not even be required when performing testing on saliva samples. Direct RT-LAMP also demonstrates a higher sensitivity than a wide variety of lateral flow tests (LFTs) in the $C_{T}<25, C_{T} \geq 25$ and overall categories, with the overall sensitivity of Direct RT-LAMP on saliva samples achieving a higher overall sensitivity than 94 out of 96 LFTs previously evaluated $^{43}$. We found that the correlation between PCR $C_{T}$ value and the Direct RT-LAMP Tp was weaker for saliva than for swabs, which may reflect the PCR $C_{T}$ value being from a naso-pharyngeal swab and recognised time course differences between initial viral infection of the salivary glands and later infection of the respiratory tract ${ }^{26,30}$.

Previous studies have described the importance of identifying asymptomatic individuals, particularly those with high viral loads ${ }^{28,44-48}$. The ability of the Direct RT-LAMP assay to reliably detect individuals with medium-high viral loads in a simple to collect, non-invasive sampling process highlights the suitability of this assay for both symptomatic and asymptomatic population screening. This is particularly important in healthcare and care home staff where the use of asymptomatic COVID-19 screening would reduce the risk of onward transmission of SARS-CoV-2, consequently maintaining NHS capacity and Social Care capacity and more importantly, reducing the risk to vulnerable individuals present within those environments ${ }^{36}$.

It is important to note that when designing surveillance strategies for asymptomatic infection testing as an intervention to reduce transmission, frequency of testing and result turnaround time may be considered more significant than diagnostic sensitivity ${ }^{49}$. 'Gold standard' tests with high sensitivity such as RT-qPCR generally need to be performed in centralised testing facilities, often resulting in increased reporting times, leading to a less effective control of viral transmission ${ }^{49}$. In contrast, point of care tests 
medRxiv preprint doi: https://doi.org/10.1101/2021.06.28.21259398; this version posted January $12,2022$. The copyright holder for this preprint (which was not certified by peer review) is the author/funder, who has granted medRxiv a license to display the preprint in It is made available under a CC-BY-NC-ND 4.0 International license.

479 such as Lateral flow tests (LFT) $)^{50,43}$ or those requiring only a basic/mobile laboratory set-up such as Direct 480 RT-LAMP, which have the ability to produce rapid results, can be performed frequently e.g., daily or 481 multiple times per week. Consequently, the likelihood of sampling an individual when their viral load is 482 highest as seen in the early, often pre-symptomatic stages of infection increases, maximising the 483 probability of rapidly detecting infectious cases, allowing prompt isolation. In this use case sampling and 484 testing frequency using a rapid assay with suitable accuracy in detection of medium-high viral loads, but 485 not necessarily optimal sensitivity over the whole range including low to very low viral loads, is desirable or necessary ${ }^{49,51}$. Frequent on-site testing of asymptomatic NHS healthcare workers using Direct RT-LAMP has been successfully implemented in the pilot study described here; and continues to be utilised. DirectRT-LAMP has also been used in a mass community based pilot in school and higher education settings ${ }^{36}$, to identify those individuals who may have been missed when surveillance relies only on symptomatic individuals coming forward for testing. With the use of mobile or pop-up laboratories, Direct RT-LAMP could also be used for risk-based mass testing, for example, targeting specific geographical areas or vulnerable groups. The potential also exists for lyophilisation of the Direct RT-LAMP reagents reported in other studies 52,53 , which would minimise the necessity for trained personnel by reducing pipetting steps and the requirement for a cold chain, allowing greater capacity of the assay in multi-use case scenarios including point-of-care and in low- and middle-income countries (LMICs).

Several experiments typical of a diagnostic performance evaluation were not performed as part of this study, as they had been performed and reported previously. This included both analytical specificity, which when tested against a panel of respiratory pathogens causing indistinguishable clinical signs to COVID-19, demonstrated a high level of analytical specificity (100\% in this case) $)^{3}$ and analytical sensitivity of the Direct RT-LAMP, which is reported to detect $1000 \mathrm{cp} / \mathrm{m}^{3,36,41}$. Additionally, the RNA and Direct RTLAMP assays evaluated as part of this study have been shown to reliably detect the emerging variants of concern (VOC) including the B.1.1.7 alpha variant, the 501Y.V2 beta variant, the P1 gamma variant and the new rapidly spreading B.1.617.2 delta variant ${ }^{54,55}$ (https://www.gov.uk/government/collections/newsars-cov-2-variant (accessed June, 2021). The emergence of further VOC could lead to a criticism of the RT-LAMP assay due its reliance on a single target, ORF1ab, where mutations in the target region in a sample could lead to false negatives. For RT-qPCR this has been observed during the current pandemic ${ }^{56-}$ ${ }^{58}$ where at least a dual target assay is recommended ${ }^{59}$. However, this is less likely to occur for the RTLAMP assay used in this pilot evaluation. Firstly, due to the multiple sets of primer pairs utilised, three pairs, with two pairs within the target region. This builds in redundancy to mutation not unlike a duplex RT-qPCR. Secondly, the ORF1ab region is highly conserved and crucial for viral replication and fitness in 511 SARS-CoV-2. As a result, these regions are well maintained using a proofreading system via the nsp14 protein $^{60}$ resulting in a more stable genome compared to many other RNA viruses. 
medRxiv preprint doi: https://doi.org/10.1101/2021.06.28.21259398; this version posted January $12,2022$. The copyright holder for this preprint (which was not certified by peer review) is the author/funder, who has granted medRxiv a license to display the preprint in It is made available under a CC-BY-NC-ND 4.0 International license .

513 The authors highlight the importance of incorporating an inhibition control into the next iteration of the 514 RT-LAMP assays. Although the paired RT-LAMP and RT-qPCR data from this study show a good correlation 515 and any false negative results were likely due to the analytical sensitivity of the RT-LAMP assay, not 516 sample driven inhibition. To this end, a control primer set by OptiGene Ltd was evaluated (PS-0010), 517 targeting the human ribosomal protein LO gene. Preliminary analysis of the inhibition control primers 518 showed consistent detection across 279 saliva and 381 combined naso/oropharyngeal swab samples 519 using both RNA and Direct RT-LAMP (manuscript in preparation). Incorporation of this inhibition control 520 into the RT-LAMP assays would alleviate a potential limitation of the current assays and further support 521 quality assurance for use within a clinical diagnostic setting. One further limitation to LAMP assays is the 522 potential for contamination from assay product which can be significant. LAMP assays produce vast 523 amounts which can persist in the environment not only causing potential false positive results in 524 subsequent testing but also anomalous results in laboratory workers who are part of a SARS-CoV-2 testing 525 programme ${ }^{61}$. Therefore, it is crucial that appropriate waste streams are in place to mitigate this risk.

526 This study demonstrated high sensitivity and specificity for a novel sample preparation method used for 527 SARS-CoV-2 Direct RT-LAMP, particularly in samples from which the individual would likely be considered 528 infectious, highlighting the usefulness of saliva as a simple to collect, non-invasive sample type. The highly 529 sensitive RNA RT-LAMP assay provides a rapid alternative with a reliance on differing reagents and 530 equipment to RT-qPCR testing, thus providing additional diagnostic capacity and redundancy through 531 diversity. Direct RT-LAMP may complement existing surveillance tools for SARS-CoV-2 testing including 532 other point-of-care and laboratory-based diagnostics and is applicable to a variety of clinical scenarios, 533 such as frequent, interval-based testing of asymptomatic individuals that may be missed when reliance is 534 on symptomatic testing alone. However, care should be taken when considering frequency of testing, 535 messaging around the role and interpretation of asymptomatic rapid tests, integration of data storage and access, and the challenges faced when scaling up surveillance to large populations.

The role out of a new testing strategy can often throw up interesting and unexpected experiences. These collective experiences and lessons learnt from setting up an NHS asymptomatic staff testing programme using Direct RT-LAMP will be shared in a future publication.

\section{Conclusions}

Rapid diagnostic testing at scale to identify and isolate symptomatic and asymptomatic individuals potentially transmitting infectious SARS-CoV-2 is an essential part of the response to the COVID-19 pandemic. RT-LAMP on both extracted RNA and directly on crude samples potentially provides faster turnaround times than reverse-transcriptase quantitative real-time PCR testing, with a higher sensitivity and specificity than antigen lateral flow devices. Increasing evidence points to potential benefits of SARS- 
medRxiv preprint doi: https://doi.org/10.1101/2021.06.28.21259398; this version posted January $12,2022$. The copyright holder for this preprint (which was not certified by peer review) is the author/funder, who has granted medRxiv a license to display the preprint in It is made available under a CC-BY-NC-ND 4.0 International license .

547 CoV-2 testing using saliva rather than nasopharyngeal/oropharyngeal swabs, therefore a multi-site 548 evaluation of an improved simple sample preparation method for Direct SARS-CoV-2 RT-LAMP was 549 undertaken. This study demonstrated that the RNA RT-LAMP assay has high sensitivity and specificity, 550 providing a rapid alternative to RT-qPCR testing with a reliance on differing reagents and equipment. The 551 simple SARS-CoV-2 Direct RT-LAMP preparation method also demonstrated high sensitivity and specificity 552 for detecting SARS-CoV-2 in saliva and naso/oropharyngeal swabs from asymptomatic and symptomatic 553 individuals, notably in saliva samples from which the individual would likely be considered infectious. The 554 findings highlight the usefulness of saliva as a simple to collect, non-invasive sample type, potentially 555 applicable for interval-based testing of asymptomatic individuals. 
medRxiv preprint doi: https://doi.org/10.1101/2021.06.28.21259398; this version posted January $12,2022$. The copyright holder for this preprint (which was not certified by peer review) is the author/funder, who has granted medRxiv a license to display the preprint in It is made available under a CC-BY-NC-ND 4.0 International license.

\section{References}

1. Zhang J, Dong X, Cao Y, Yuan Y, Yang Y, Yan Y, Akdis C, Gao Y. Clinical characteristics of 140 patients infected with SARS-CoV-2 in Wuhan, China. Allergy Eur J Allergy Clin Immunol, 2020, 75:1730-41

2. Corman VM, Landt O, Kaiser M, Molenkamp R, Meijer A, Chu DKW, Bleicker T, Brünink S, Schneider J, Schmidt ML, Mulders DGJC, Haagmans BL, Van Der Veer B, Van Den Brink S, Wijsman L, Goderski G, Romette JL, Ellis J, Zambon M, Peiris M, Goossens H, Reusken C, Koopmans MPG, Drosten C. Detection of 2019 novel coronavirus (2019-nCoV) by real-time RTPCR. Eurosurveillance, 2020, 25:23-30

3. Fowler VL, Armson B, Gonzales JL, Wise EL, Howson ELA, Vincent-Mistiaen Z, Fouch S, Maltby CJ, Grippon S, Munro S, Jones L, Holmes T, Tillyer C, Elwell J, Sowood A, de Peyer O, Dixon S, Hatcher T, Patrick H, Laxman S, Walsh C, Andreou M, Morant N, Clark D, Moore N, Houghton R, Cortes NJ, Kidd SP. A highly effective reverse-transcription loop-mediated isothermal amplification (RTLAMP) assay for the rapid detection of SARS-CoV-2 infection. J Infect, 2020, 82:117-25

4. Moreira VM, Mascarenhas P, Machado V, Botelho J, Mendes JJ, Taveira N, Almeida MG. Diagnosis of SARS-Cov-2 Infection by RT-PCR Using Specimens Other Than Naso- and Oropharyngeal Swabs: A Systematic Review and Meta-Analysis Vânia. Diagnostics, 2021, 11

5. de Paula Eduardo F, Bezinelli LM, de Araujo CAR, Moraes JVV, Birbrair A, Pinho JRR, Hamerschlak N, Al-Hashimi I, Heller D. Self-collected unstimulated saliva, oral swab, and nasopharyngeal swab specimens in the detection of SARS-CoV-2. Clin Oral Investig, 2021. https://doi.org/10.1007/s00784-021-04129-7

6. Kuo A, Teo J, Choudhury Y, Tan IB, Cher CY, Chew SH, Wan ZY, Tim L, Cheng E, Lin L, Oon E, Tan $\mathrm{MH}$. Saliva is more sensitive than nasopharyngeal or nasal swabs for diagnosis of asymptomatic and mild COVID-19 infection. Sci Rep, 2021, 11:3134

7. Ott IM, Strine MS, Watkins AE, Boot M, Kalinich CC, Harden CA, Vogels CBF, Casanovas-Massana A, Moore AJ, Muenker MC, Nakahata M, Tokuyama M, Nelson A, Fournier J, Bermejo S, Campbell M, Datta R, Cruz CSD, Farhadian SF, Ko Al, Iwasaki A, Grubaugh ND, Wilen CB, Wyllie AL. Stability of SARS-CoV-2 RNA in nonsupplemented saliva. Emerg Infect Dis, 2021, 27:1146-50

8. Matic N, Stefanovic A, Leung V, Lawson T, Ritchie G, Li L, Champagne S, Romney MG, Lowe CF. Practical challenges to the clinical implementation of saliva for SARS-CoV-2 detection. Eur J Clin Microbiol Infect Dis, 2021, 40:447-50

9. Fajnzylber J, Regan J, Coxen K, Corry H, Wong C, Rosenthal A, Worrall D, Giguel F, Piechockatrocha A, Atyeo C, Fischinger S, Chan A, Flaherty KT, Hall K, Dougan M, Ryan ET, Gillespie E, Chishti R, Li Y, Jilg N, Hanidziar D, Baron RM, Baden L, Tsibris AM, Armstrong KA, Kuritzkes DR, Alter G, Walker BD, Yu X, Li JZ, Consortium M. SARS-CoV-2 viral load is associated with increased disease severity and mortality. Nat Commun, 2020, 11:5493 
medRxiv preprint doi: https://doi.org/10.1101/2021.06.28.21259398; this version posted January $12,2022$. The copyright holder for this preprint (which was not certified by peer review) is the author/funder, who has granted medRxiv a license to display the preprint in It is made available under a CC-BY-NC-ND 4.0 International license.

10. Borghi E, Massa V, Zuccotti G, Wyllie AL. Testing Saliva to Reveal the Submerged Cases of the COVID-19 Iceberg. Front Microbiol, 2021, 12:10-2

11. Lee RA, Herigon JC, Benedetti A, Pollock NR, Denkinger CM, Scholar G. Performance of Saliva, Oropharyngeal Swabs, and Nasal Swabs for SARS-CoV-2 Molecular Detection: a Systematic Review and Meta-analysis, 2021:1-17

12. Wong SCY, Tse H, Siu HK, Kwong TS, Chu MY, Yat F, Yau S, Yu I, Cheung Y, Wing C, Tse S, Poon KC, Cheung KC, Wu TC, Wai J, Chan M, Cheuk W, Lung DC. Posterior Oropharyngeal Saliva for the Detection of Severe Acute Respiratory Syndrome Coronavirus 2 ( SARS-CoV-2 ), 2020, 2:2939-46

13. Iwasaki S, Fujisawa S, Nakakubo S, Kamada K, Yamashita Y, Fukumoto T, Sato K, Oguri S, Taki K, Senjo H, Sugita J, Hayasaka K, Konno S, Nishida M, Teshima T. Comparison of SARS-CoV-2 detection in nasopharyngeal swab and saliva. J Infect, 2020, 81:e145-7

14. Aydin S, Benk IG, Geckil AA. May viral load detected in saliva in the early stages of infection be a prognostic indicator in COVID-19 patients? J Virol Methods, 2021, 294

15. Zhu J, Guo J, Xu Y, Chen X. Viral dynamics of SARS-CoV-2 in saliva from infected patients. J Infect, 2020, 81:e48-50

16. Azzi L, Baj A, Alberio T, Lualdi M, Veronesi G, Carcano G, Ageno W, Gambarini C, Maffioli L, Saverio S Di, Gasperina DD, Genoni AP, Premi E, Donati S, Azzolini C, Grandi AM, Dentali F, Tangianu F, Sessa F, Maurino V, Tettamanti L, Siracusa C, Vigezzi A, Monti E, lori V, lovino D, letto G, Grossi PA, Tagliabue A, Fasano M. Rapid Salivary Test suitable for a mass screening program to detect SARS-CoV-2: A diagnostic accuracy study. J Infect, 2020, 81:e75-8

17. Yokota I, Shane PY, Okada K, Unoki Y, Yang Y, Inao T, Sakamaki K, Iwasaki S, Hayasaka K, Sugita J, Nishida M, Fujisawa S, Teshima T. Mass Screening of Asymptomatic Persons for Severe Acute Respiratory Syndrome Coronavirus 2 Using Saliva. Clin Infect Dis, 2021, 73:e559-65

18. Masse S, Bonnet C, Vilcu AM, Benamar H, Swital M, van der Werf S, Carrat F, Hanslik T, Blanchon T, Falchi A. Are posterior oropharyngeal saliva specimens an acceptable alternative to nasopharyngeal sampling for the monitoring of sars-cov-2 in primary-care settings? Viruses, 2021, 13:1-11

19. Howson ELA, Kidd SP, Armson B, Goring A, Sawyer J, Cassar C, Cross D, Lewis T, Hockey J, Rivers S, Cawthraw S, Banyard A, Anderson P, Rahou S, Andreou M, Morant N, Clark D, Walsh C, Laxman S, Houghton R, Slater-Jefferies J, Costello P, Brown I, Cortes N, Godfrey KM, Fowler VL. Preliminary optimisation of a simplified sample preparation method to permit direct detection of SARS-CoV-2 within saliva samples using reverse-transcription loop-mediated isothermal amplification (RT-LAMP). J Virol Methods, 2021, 289

20. Reitsma JB, Glas AS, Rutjes AWS, Scholten RJPM, Bossuyt PM, Zwinderman AH. Bivariate analysis of sensitivity and specificity produces informative summary measures in diagnostic reviews. J Clin Epidemiol, 2005, 58:982-90 
medRxiv preprint doi: https://doi.org/10.1101/2021.06.28.21259398; this version posted January $12,2022$. The copyright holder for this preprint (which was not certified by peer review) is the author/funder, who has granted medRxiv a license to display the preprint in It is made available under a CC-BY-NC-ND 4.0 International license.

631 21. Bhargava A. Dynamic aspects of ORF1ab and N RNA cycle threshold values among COVID-19 632 patients in China. Infect Genet Evol, 2021, 87:104657

633 22. Alexandersen S, Chamings A, Bhatta TR. SARS-CoV-2 genomic and subgenomic RNAs in diagnostic 634 samples are not an indicator of active replication. Nat Commun, 2020, 11:6059

635 23. Xu T, Chen C, Zhu Z, Cui M, Chen C, Dai H, Xue Y. Clinical features and dynamics of viral load in 636 imported and non-imported patients with COVID-19. Int J Infect Dis, 2020, 94:68-71

637 24. Huang N, Pérez P, Kato T, Mikami Y, Okuda K, Gilmore RC, et al. SARS-CoV-2 infection of the oral 638 cavity and saliva. Nat Med, 2021, 27:892-903

639 25. To KKW, Tsang OTY, Leung WS, Tam AR, Wu TC, Lung DC, Yip CCY, Cai JP, Chan JMC, Chik TSH, 640 Lau DPL, Choi CYC, Chen LL, Chan WM, Chan KH, Ip JD, Ng ACK, Poon RWS, Luo CT, Cheng VCC, 641 642 643 644 645 646 647 648 649 650 651 652 653 654 Chan JFW, Hung IFN, Chen Z, Chen H, Yuen KY. Temporal profiles of viral load in posterior oropharyngeal saliva samples and serum antibody responses during infection by SARS-CoV-2: an observational cohort study. Lancet Infect Dis, 2020, 20:565-74

26. Tan SH, Allicock O, Armstrong-Hough M, Wyllie AL. Saliva as a gold-standard sample for SARSCoV-2 detection. Lancet Respir Med, 2021, 2600:19-21

27. Savela ES, Winnett A, Romano AE, Porter MK, Shelby N, Akana R, Ji J. Quantitative SARS-CoV-2 viral-load curves in paired saliva and nasal swabs inform appropriate respiratory sampling site and analytical test sensitivity required for earliest viral detection. MedRxiv, 2021:1-37

28. Yang Q, Saldi TK, Gonzales PK, Lasda E, Decker CJ, Tat KL, Fink MR, Hager CR, Davis JC, Ozeroff CD, Muhlrad D, Clark SK, Fattor WT, Meyerson NR, Paige CL, Gilchrist AR, Barbachano-Guerrero A, Worden-Sapper ER, Wu SS, Brisson GR, McQueen MB, Dowell RD, Leinwand L, Parker R, Sawyer SL. Just $2 \%$ of SARS-CoV-2-positive individuals carry $90 \%$ of the virus circulating in communities. Proc Natl Acad Sci U S A, 2021, 118:1-6

30. Wyllie AL, Fournier J, Casanovas-Massana A, Campbell M, Tokuyama M, Vijayakumar P, et al. Saliva or Nasopharyngeal Swab Specimens for Detection of SARS-CoV-2. N Engl J Med, 2020, 383:1283-6

31. Vogels CBF, Watkins AE, Harden CA, Brackney DE, Shafer J, Wang J, et al. SalivaDirect: A simplified and flexible platform to enhance SARS-CoV-2 testing capacity. Med, 2021, 2:263280.e6

32. Buck MD, Poirier EZ, Cardoso A, Frederico B, Canton J, Barrell S, et al. SARS-CoV-2 detection by a clinical diagnostic RT-LAMP assay. Wellcome Open Res, 2021, 6:9

33. Kellner MJ, Matl M, Ross JJ, Schnabl J, Handler D, Heinen R, Schaeffer J, Hufnagl P, Indra A, 
medRxiv preprint doi: https://doi.org/10.1101/2021.06.28.21259398; this version posted January $12,2022$. The copyright holder for this preprint (which was not certified by peer review) is the author/funder, who has granted medRxiv a license to display the preprint in It is made available under a CC-BY-NC-ND 4.0 International license.

Dekens MP, Fritsche-Polanz R, Födinger M, Zuber J, Allerberger F, Pauli A, Brennecke J, BioCenter Program V. Head-to-head comparison of direct-input RT-PCR and RT-LAMP against RT-qPCR on extracted RNA for rapid SARS-CoV-2 diagnostics. MedRxiv, 2021:2021.01.19.21250079

34. Ochert AS, Boulter AW, Birnbaum W, Johnson NW, Teo CG. Inhibitory effect of salivary fluids on PCR: Potency and removal. PCR Methods Appl, 1994, 3:365-8

35. Wilson IG. Inhibition and facilitation of nucleic acid amplification. Appl Environ Microbiol, 1997, 63:3741-51

36. Department of Health and Social Care. Rapid evaluation of OptiGene RT-LAMP assay (direct and RNA formats). Department of Health and Social Care. United Kingdom. 2020

37. La Scola B, Le Bideau M, Andreani J, Hoang VT, Grimaldier C, Colson P, Gautret P, Raoult D. Viral RNA load as determined by cell culture as a management tool for discharge of SARS-CoV-2 patients from infectious disease wards. Eur J Clin Microbiol Infect Dis, 2020, 39:1059-61

38. Bullard J, Dust K, Funk D, Strong JE, Alexander D, Garnett L, Boodman C, Bello A, Hedley A, Schiffman Z, Doan K, Bastien N, Li Y, van Caeseele PG, Poliquin G. Predicting infectious severe acute respiratory syndrome coronavirus 2 from diagnostic samples. Clin Infect Dis, 2020,

71:2663-6

39. Wölfel R, Corman VM, Guggemos W, Seilmaier M, Zange S, Müller MA, Niemeyer D, Jones TC, Vollmar P, Rothe C, Hoelscher M, Bleicker T, Brünink S, Schneider J, Ehmann R, Zwirglmaier K, Drosten C, Wendtner C. Virological assessment of hospitalized patients with COVID-2019. Nature, 2020, 581:465-9

40. Marc A, Kerioui M, Blanquart F, Bertrand J, Mitjà O, Corbacho-Monné M, Marks M, Guedj J. Quantifying the relationship between SARS-CoV-2 viral load and infectiousness. Elife, 2021, 10:e69302

41. Fowler DV, Douglas DA, Godfrey PK, Williams PA, Beggs PA, Kidd S, Cortes DN, Wilcox PM, Davies DK, Smith M, Hill PDS. Critical evaluation of the methodology used by Wilson-Davies et al., (2020) entitled “Concerning the Optigene Direct LAMP assay, and it`s use in at-risk groups and hospital staff." J Infect, 2021, 82:282-327

42. Hanson KE, Barker AP, Hillyard DR, Gilmore N, Barrett JW, Orlandi RR, Shakir SM. Self-collected anterior nasal and saliva specimens versus healthcare worker-collected nasopharyngeal swabs for the molecular detection of SARS-CoV-2. J Clin Microbiol, 2020, 58:e01824-20

43. Scheiblauer H, Filomena A, Nitsche A, Puyskens A, Corman VM, Drosten C, Zwirglmaier K, Lange C, Emmerich P, Müller M, Knauer O, Nübling CM. Comparative sensitivity evaluation for 122 CEmarked rapid diagnostic tests for SARS-CoV-2 antigen, Germany, September 2020 to April 2021. Eurosurveillance, 2021, 26:1-13

44. Nikolai LA, Meyer CG, Kremsner PG, Velavan TP. Asymptomatic SARS Coronavirus 2 infection: Invisible yet invincible. Int J Infect Dis, 2020, 100:112-6 
medRxiv preprint doi: https://doi.org/10.1101/2021.06.28.21259398; this version posted January $12,2022$. The copyright holder for this preprint (which was not certified by peer review) is the author/funder, who has granted medRxiv a license to display the preprint in It is made available under a CC-BY-NC-ND 4.0 International license .

45. Marks M, Millat P, Ouchi D, Roberts C, Alemany A, Corbacho-Monné M, Ubals M, Vall-Mayans M, G-Beiras C, Prat N, Ara J, Clotet B, Mitjà O. Transmission of COVID-19 in 282 clusters in Catalonia, Spain: A cohort study. Lancet Infect Dis, 2021, 21:6290

46. Byambasuren O, Cardona M, Bell K, Clark J, McLaws ML, Glasziou P. Estimating the extent of asymptomatic COVID-19 and its potential for community transmission: Systematic review and meta-analysis. J Assoc Med Microbiol Infect Dis Canada, 2020, 5:223-34

47. Buitrago-Garcia D, Egli-Gany D, Counotte MJ, Hossmann S, Imeri H, Ipekci AM, Salanti G, Low N. Occurrence and transmission potential of asymptomatic and presymptomatic SARS-CoV-2 infections: A living systematic review and meta-analysis. PLoS Med, 2020, 17:e1003346

48. Johansson MA, Quandelacy TM, Kada S, Prasad PV, Steele M, Brooks JT, Slayton RB, Biggerstaff M, Butler JC. SARS-CoV-2 Transmission from People without COVID-19 Symptoms. JAMA Netw Open, $2021,4: 1-8$

49. Larremore DB, Wilder B, Lester E, Shehata S, Burke JM, Hay JA, Tambe M, Mina MJ, Parker R. Test sensitivity is secondary to frequency and turnaround time for COVID-19 screening. Sci Adv, 2021, 7:1-11

50. Lee LYW, Rozmanowski S, Pang M, Charlett A, Anderson C, Hughes GJ, Barnard M, Peto L, Vipond R, Sienkiewicz A, Hopkins S, Bell J, Crook DW, Gent N, Walker AS, Peto TEA, Eyre DW. SARS-CoV-2 infectivity by viral load, $\mathrm{S}$ gene variants and demographic factors and the utility of lateral flow devices to prevent transmission. Clin Infect Dis, 2021, May:ciab421

51. Kissler SM, Fauver JR, Mack C, Olesen SW, Tai C, Shiue KY, Kalinich CC, Jednak S, Ott IM, Vogels CBF, Wohlgemuth J, Weisberger J, DiFiori J, Anderson DJ, Mancell J, Ho DD, Grubaugh ND, Grad $\mathrm{YH}$. Viral dynamics of acute SARS-CoV-2 infection and applications to diagnostic and public health strategies. PLoS Biol, 2021, 19:1-17

52. Howson ELA, Armson B, Madi M, Kasanga CJ, Kandusi S, Sallu R, Chepkwony E, Siddle A, Martin P, Wood J, Mioulet V, King DP, Lembo T, Cleaveland S, Fowler VL. Evaluation of Two Lyophilized Molecular Assays to Rapidly Detect Foot-and-Mouth Disease Virus Directly from Clinical Samples in Field Settings. Transbound Emerg Dis, 2017, 64:861-71

53. Armson B, Walsh C, Morant N, Fowler VL, Knowles NJ, Clark D. The development of two fieldready reverse transcription loop-mediated isothermal amplification assays for the rapid detection of Seneca Valley virus 1. Transbound Emerg Dis, 2019, 66:497-504

54. Horby P, Huntley C, Davies N, Edmunds J, Ferguson N, Medley G, Hayward A, Cevik M, Semple C. NERVTAG note on B.1.1.7 severity. Sage, 2021:5-8

55. Tegally H, Wilkinson E, Giovanetti M, Iranzadeh A, Fonseca V, Giandhari J, et al. Emergence and rapid spread of a new severe acute respiratory syndrome-related coronavirus 2 (SARS-CoV-2) lineage with multiple spike mutations in South Africa. MedRxiv, 2020, 2

56. Vanaerschot M, Mann SA, Webber JT, Kamm J, Bell SM, Bell J, Hong SN, Nguyen MP, Chan LY, 
medRxiv preprint doi: https://doi.org/10.1101/2021.06.28.21259398; this version posted January $12,2022$. The copyright holder for this preprint (which was not certified by peer review) is the author/funder, who has granted medRxiv a license to display the preprint in It is made available under a CC-BY-NC-ND 4.0 International license .

Bhatt KD, Tan M, Detweiler AM, Espinosa A, Wu W, Batson J, Dynerman D, Wadford DA, Puschnik AS, Neff N, Ahyong V, Miller S, Ayscue P, Tato CM, Paul S, Kistler AL, DeRisi JL, Crawford ED. Identification of a Polymorphism in the N Gene of SARS-CoV-2 That Adversely Impacts Detection by Reverse Transcription-PCR. J Clin Microbiol, 2020, 59:e02369-20

57. Hasan MR, Sundararaju S, Manickam C, Mirza F, Al-Hail H, Lorenz S, Tang P. A Novel Point Mutation in the N Gene of SARS-CoV-2 May Affect the Detection of the Virus by Reverse Transcription-Quantitative PCR. J Clin Microbiol, 2021, 59:e03278-20

58. Artesi M, Bontems S, Göbbels P, Franckh M, Maes P, Boreux R, Meex C, Melin P, Hayette M-P, Bours V, Durkin K. A Recurrent Mutation at Position 26340 of SARS-CoV-2 Is Associated with Failure of the E Gene Quantitative Reverse Transcription-PCR Utilized in a Commercial DualTarget Diagnostic Assay. J Clin Microbiol, 2020, 58:e01598-20

59. Wang R, Hozumi Y, Yin C, Wei G-W. Mutations on COVID-19 diagnostic targets. Genomics, 2020, 112:5204-13

60. Rausch JW, Capoferri AA, Katusiime MG, Patro SC, Kearney MF. Low genetic diversity may be an Achilles heel of SARS-CoV-2. Proc Natl Acad Sci, 2020, 117:24614 LP - 24616

61. Robinson-McCarthy LR, Mijalis AJ, Filsinger GT, de Puig H, Donghia NM, Schaus TE, Rasmussen RA, Ferreira R, Lunshof JE, Chao G, Ter-Ovanesyan D, Dodd O, Kuru E, Sesay AM, Rainbow J, Pawlowski AC, Wannier TM, Angenent-Mari NM, Najjar D, Yin P, Ingber DE, Tam JM, Church GM. Laboratory-Generated DNA Can Cause Anomalous Pathogen Diagnostic Test Results. Microbiol Spectr, 2021, 9:1-9 
medRxiv preprint doi: https://doi.org/10.1101/2021.06.28.21259398; this version posted January $12,2022$. The copyright holder for this preprint (which was not certified by peer review) is the author/funder, who has granted medRxiv a license to display the preprint in It is made available under a CC-BY-NC-ND 4.0 International license .

761

Tables

762

763

Table 1. Diagnostic sensitivity and specificity of RNA RT-LAMP on swabs compared with RT-qPCR

\begin{tabular}{|c|c|c|c|c|c|c|c|}
\hline \multirow{4}{*}{$\begin{array}{l}C_{\mathrm{T}}<45 \\
\text { Swab }\end{array}$} & & RT-qPCR Pos & RT-qPCR Neg & Total & & $\%$ & $95 \% \mathrm{Cl}$ \\
\hline & RNA RT-LAMP Pos & $244^{+}$ & 1 & 245 & DSe & 96.06 & $92.88-98.12$ \\
\hline & RNA RT-LAMP Neg & 10 & 12364 & 12374 & DSp & 99.99 & $99.95-100$ \\
\hline & Total & 254 & 12365 & & & & \\
\hline \multirow{4}{*}{$\begin{array}{l}\mathrm{C}_{\mathrm{T}}<33 \\
\text { Swab }\end{array}$} & & RT-qPCR Pos & RT-qPCR Neg & Total & & $\%$ & $95 \% \mathrm{Cl}$ \\
\hline & RNA RT-LAMP Pos & 219 & 1 & 220 & DSe & 98.95 & $96.10-99.72$ \\
\hline & RNA RT-LAMP Neg & 3 & 12364 & 12367 & DSp & 99.9 & $99.95-100$ \\
\hline & Total & 222 & 12365 & & & & \\
\hline \multirow{4}{*}{$\begin{array}{l}C_{\mathrm{T}}<25 \\
\text { Swab }\end{array}$} & & RT-qPCR Pos & RT-qPCR Neg & Total & & $\%$ & $95 \% \mathrm{Cl}$ \\
\hline & RNA RT-LAMP Pos & 112 & 1 & 113 & DSe & 100 & $96.76-100$ \\
\hline & RNA RT-LAMP Neg & 0 & 12364 & 12364 & DSp & 99.9 & $99.95-100$ \\
\hline & Total & 112 & 12365 & & & & \\
\hline
\end{tabular}

764

${ }^{\dagger}$ Five samples included in this number were positive by RT-qPCR but did not have an associated $\mathrm{C}_{\mathrm{T}}$ value due to being assayed

765

on a platform that did not produce a $C_{T}$ value. DSe: Diagnostic sensitivity. DSp: Diagnostic specificity

766

767

Table 2. Diagnostic sensitivity and specificity of Direct RT-LAMP on swabs compared to RT-qPCR

\begin{tabular}{|c|c|c|c|c|c|c|c|}
\hline \multirow{4}{*}{$\begin{array}{l}\mathrm{C}_{\mathrm{T}}<45 \\
\text { Swab }\end{array}$} & & RT-qPCR Pos & RT-qPCR Neg & Total & & $\%$ & $95 \% \mathrm{Cl}$ \\
\hline & Direct RT-LAMP Pos & 140 & 0 & 140 & DSe & 70.35 & $\begin{array}{l}63.48- \\
76.60\end{array}$ \\
\hline & Direct RT-LAMP Neg & 59 & 360 & 419 & DSp & 100 & $98.98-100$ \\
\hline & Total & 199 & 360 & & & & \\
\hline \multirow{4}{*}{$\begin{array}{l}C_{T}<33 \\
\text { Swab }\end{array}$} & & RT-qPCR Pos & RT-qPCR Neg & Total & & $\%$ & $95 \% \mathrm{Cl}$ \\
\hline & Direct RT-LAMP Pos & 140 & 0 & 140 & DSe & 77.78 & $\begin{array}{l}70.99- \\
83.62\end{array}$ \\
\hline & Direct RT-LAMP Neg & 40 & 360 & 400 & DSp & 100 & $98.98-100$ \\
\hline & Total & 180 & 360 & & & & \\
\hline \multirow{4}{*}{$\begin{array}{l}C_{\mathrm{T}}<25 \\
\text { Swab }\end{array}$} & & RT-qPCR Pos & RT-qPCR Neg & Total & & $\%$ & $95 \% \mathrm{Cl}$ \\
\hline & Direct RT-LAMP Pos & 99 & 0 & 99 & DSe & 100 & $96.34-100$ \\
\hline & Direct RT-LAMP Neg & 0 & 360 & 360 & DSp & 100 & $98.98-100$ \\
\hline & Total & 99 & 360 & & & & \\
\hline
\end{tabular}

768

DSe: Diagnostic sensitivity. DSp: Diagnostic specificity 
medRxiv preprint doi: https://doi.org/10.1101/2021.06.28.21259398; this version posted January $12,2022$. The copyright holder for this preprint (which was not certified by peer review) is the author/funder, who has granted medRxiv a license to display the preprint in It is made available under a CC-BY-NC-ND 4.0 International license .

774 Table 3. Diagnostic sensitivity and specificity of RNA RT-LAMP on saliva compared to RT-qPCR

\begin{tabular}{|c|c|c|c|c|c|c|c|}
\hline \multirow{4}{*}{$\begin{array}{l}C_{T}<45 \\
\text { Saliva }\end{array}$} & & RT-qPCR Pos & RT-qPCR Neg & Total & & $\%$ & $95 \% \mathrm{Cl}$ \\
\hline & RNA RT-LAMP Pos & 125 & 1 & 126 & DSe & 80.65 & 73.54- \\
\hline & RNA RT-LAMP Neg & 30 & 12365 & 12395 & DSp & 99.99 & $99.95-100$ \\
\hline & Total & 155 & 12366 & & & & \\
\hline \multirow{5}{*}{$\begin{array}{l}\mathrm{C}_{\mathrm{T}}<33 \\
\text { Saliva }\end{array}$} & & RT-qPCR Pos & RT-qPCR Neg & Total & & $\%$ & $95 \% \mathrm{Cl}$ \\
\hline & RNA RT-LAMP Pos & 124 & 1 & 125 & DSe & 87.32 & 80.71- \\
\hline & & & & & & & 92.31 \\
\hline & RNA RT-LAMP Neg & 18 & 12365 & 12383 & DSp & 99.99 & $99.95-100$ \\
\hline & Total & 142 & 12366 & & & & \\
\hline \multirow{4}{*}{$\begin{array}{l}\mathrm{C}_{\mathrm{T}}<25 \\
\text { Saliva }\end{array}$} & & RT-qPCR Pos & RT-qPCR Neg & Total & & $\%$ & $95 \% \mathrm{Cl}$ \\
\hline & RNA RT-LAMP Pos & 57 & 1 & 58 & DSe & 100 & $93.73-100$ \\
\hline & RNA RT-LAMP Neg & 0 & 12365 & 12365 & DSp & 99.99 & $99.95-100$ \\
\hline & Total & 57 & 12366 & & & & \\
\hline
\end{tabular}

DSe: Diagnostic sensitivity. DSp: Diagnostic specificity

Table 4. Diagnostic sensitivity and specificity of Direct RT-LAMP on saliva compared to RT-qPCR.

\begin{tabular}{|c|c|c|c|c|c|c|c|}
\hline \multirow{4}{*}{$\begin{array}{l}\mathrm{C}_{\mathrm{T}}<45 \\
\text { Saliva }\end{array}$} & & RT-qPCR Pos & RT-qPCR Neg & Total & & $\%$ & $95 \% \mathrm{Cl}$ \\
\hline & Direct RT-LAMP Pos & 209 & 0 & 209 & DSe & 84.62 & $\begin{array}{l}79.50- \\
88.88\end{array}$ \\
\hline & Direct RT-LAMP Neg & 38 & $7195^{*}$ & 7233 & DSp & 100.00 & $\begin{array}{l}99.95- \\
100.00\end{array}$ \\
\hline & Total & 247 & 7195 & & & & \\
\hline \multirow{4}{*}{$\begin{array}{l}\mathrm{C}_{\mathrm{T}}<33 \\
\text { Saliva }\end{array}$} & & RT-qPCR Pos & RT-qPCR Neg & Total & & $\%$ & $95 \% \mathrm{Cl}$ \\
\hline & Direct RT-LAMP Pos & 205 & 0 & 205 & DSe & 87.61 & $\begin{array}{l}82.69- \\
91.54\end{array}$ \\
\hline & Direct RT-LAMP Neg & 29 & $7195^{*}$ & 7224 & DSp & 100.0 & $\begin{array}{l}99.95- \\
100.00\end{array}$ \\
\hline & Total & 234 & 7195 & & & & \\
\hline \multirow{4}{*}{$\begin{array}{l}\mathrm{C}_{\mathrm{T}}<25 \\
\text { Saliva }\end{array}$} & & RT-qPCR Pos & RT-qPCR Neg & Total & & $\%$ & $95 \% \mathrm{Cl}$ \\
\hline & Direct RT-LAMP Pos & 100 & 0 & 100 & DSe & 99.01 & $\begin{array}{l}94.61- \\
99.97\end{array}$ \\
\hline & Direct RT-LAMP Neg & 1 & $7195^{*}$ & 7196 & DSp & 100.0 & $\begin{array}{l}99.95- \\
100.00\end{array}$ \\
\hline & Total & 101 & 7195 & & & & \\
\hline
\end{tabular}


medRxiv preprint doi: https://doi.org/10.1101/2021.06.28.21259398; this version posted January $12,2022$. The copyright holder for this preprint (which was not certified by peer review) is the author/funder, who has granted medRxiv a license to display the preprint in It is made available under a CC-BY-NC-ND 4.0 International license .

784 Table 5. Viral culture of positive VTM from oro/pharyngeal swabs and assay results.

\begin{tabular}{|c|c|c|c|c|c|c|}
\hline \multirow{3}{*}{ Sample } & \multirow{3}{*}{$\begin{array}{c}\text { Direct } \\
\text { RT- } \\
\text { LAMP }\end{array}$} & \multirow{3}{*}{$\begin{array}{c}\text { RNA } \\
\text { RT- } \\
\text { LAMP }\end{array}$} & \multicolumn{3}{|c|}{$\begin{array}{c}C_{T} \text { values for each } R T-q P C R \\
\text { assay }\end{array}$} & \multirow{3}{*}{ CPE } \\
\hline & & & \multirow{2}{*}{$\begin{array}{c}\text { Genesig } \\
\text { RDRP } \\
\text { gene }\end{array}$} & VIASURE & \multirow{2}{*}{\begin{tabular}{|c} 
SARS- \\
CoV-2 E \\
gene \\
Sarbeco \\
assay
\end{tabular}} & \\
\hline & & & & ORF1ab & & \\
\hline 1 & POS & POS & 19.9 & 18.7 & 17.8 & $\mathrm{CPE}+$ \\
\hline 2 & POS & POS & 21.3 & 19.9 & 19.0 & $\mathrm{CPE}+$ \\
\hline 3 & POS & POS & 21.6 & 19.1 & 18.5 & $\mathrm{CPE}+$ \\
\hline 4 & POS & POS & 22.6 & 20.8 & 19.8 & $\mathrm{CPE}+$ \\
\hline 5 & POS & POS & 22.9 & 21.6 & 21.0 & $\mathrm{CPE}+$ \\
\hline 6 & POS & POS & 23.7 & 20.6 & 20.6 & $\mathrm{CPE}+$ \\
\hline 7 & NEG & POS & - & ND & ND & No CPE \\
\hline 8 & NEG & POS & 39.2 & ND & ND & No CPE \\
\hline 9 & NEG & POS & 35.2 & ND & ND & No CPE \\
\hline 10 & NEG & NEG & 34.6 & $N D$ & ND & No CPE \\
\hline 11 & NEG & POS & 35.4 & ND & ND & No CPE \\
\hline 12 & NEG & POS & 36.2 & ND & ND & No CPE \\
\hline 13 & POS & POS & 35.8 & ND & ND & No CPE \\
\hline 14 & POS & POS & 34.5 & ND & ND & No CPE \\
\hline 15 & NEG & POS & 35.1 & ND & ND & No CPE \\
\hline 16 & POS & POS & 30.0 & ND & ND & No CPE \\
\hline 17 & POS & POS & 32.3 & ND & ND & No CPE \\
\hline 18 & NEG & POS & 34.6 & ND & ND & No CPE \\
\hline 19 & POS & POS & 31.3 & ND & ND & No CPE \\
\hline 20 & NEG & POS & 30.3 & ND & ND & No CPE \\
\hline 21 & NEG & POS & 30.0 & ND & ND & No CPE \\
\hline 22 & NEG & POS & 31.5 & ND & ND & No CPE \\
\hline 23 & NEG & POS & 30.7 & ND & ND & $\mathrm{CPE}+$ \\
\hline 24 & POS & POS & 29.9 & ND & ND & No CPE \\
\hline 25 & POS & POS & 29.4 & ND & ND & No CPE \\
\hline 26 & NEG & POS & 28.2 & ND & ND & $\mathrm{CPE}+$ \\
\hline
\end{tabular}


medRxiv preprint doi: https://doi.org/10.1101/2021.06.28.21259398; this version posted January 12, 2022. The copyright holder for this preprint (which was not certified by peer review) is the author/funder, who has granted medRxiv a license to display the preprint in It is made available under a CC-BY-NC-ND 4.0 International license .

\section{Figure Legends}

Figure 1. Time to positivity [Tp] in minutes plotted against RT-qPCR Cycle Threshold [ $\left.\mathrm{C}_{\mathrm{T}}\right]$ for each combination of method and sample type. Samples which were negative by RT-qPCR are not shown. Samples which were negative by RT-LAMP are shown with 0 time to positivity. Results of linear ordinary least squared regression are shown for samples which were RT-LAMP positive with the regression line and corresponding $95 \%$ confidence interval represented by the blue line and light blue shaded regions respectively.

Figure 2. Performance of the RNA RT-LAMP and Direct RT-LAMP assays on both saliva and swab samples according to viral load groupings.

Figure 3. Forest plots for Direct RT-LAMP per sample type showing site heterogeneity in sensitivity and specificity, with overall estimates and the resulting expected sensitivity and specificity retrieved from each respective bivariate random effects model.

Figure 4: Forest plots for RNA RT-LAMP per sample type showing site heterogeneity in sensitivity and specificity, with overall estimates and the resulting expected sensitivity and specificity retrieved from each respective bivariate random effects model. 
medRxiv preprint doi: https://doi.org/10.1101/2021.06.28.21259398; this version posted January 12, 2022. The copyright holder for this preprint (which was not certified by peer review) is the author/funder, who has granted medRxiv a license to display the preprint in It is made available under a CC-BY-NC-ND 4.0 International license

Figure 1
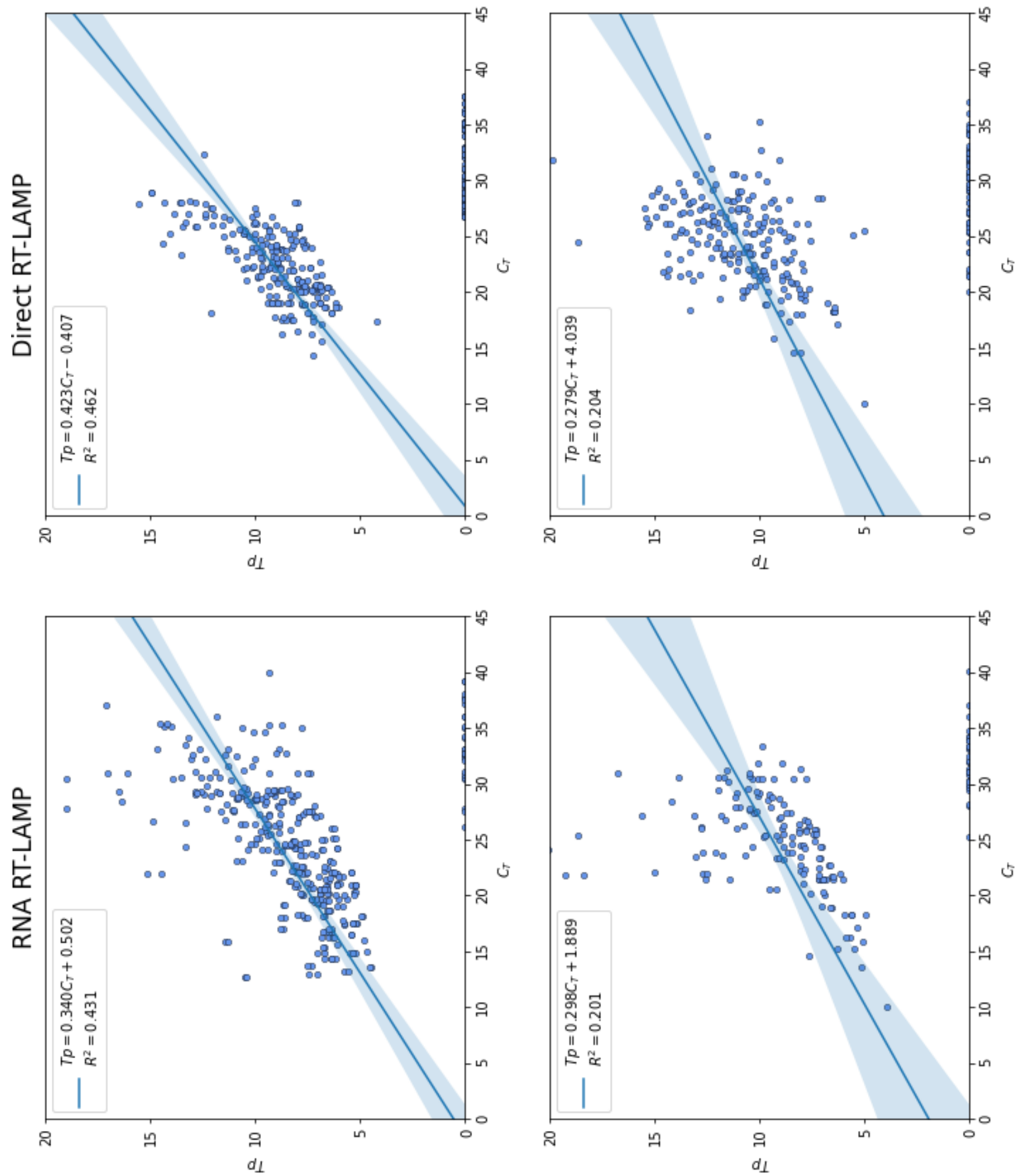
medRxiv preprint doi: https://doi.org/10.1101/2021.06.28.21259398; this version posted January 12, 2022. The copyright holder for this preprint (which was not certified by peer review) is the author/funder, who has granted medRxiv a license to display the preprint in It is made available under a CC-BY-NC-ND 4.0 International license
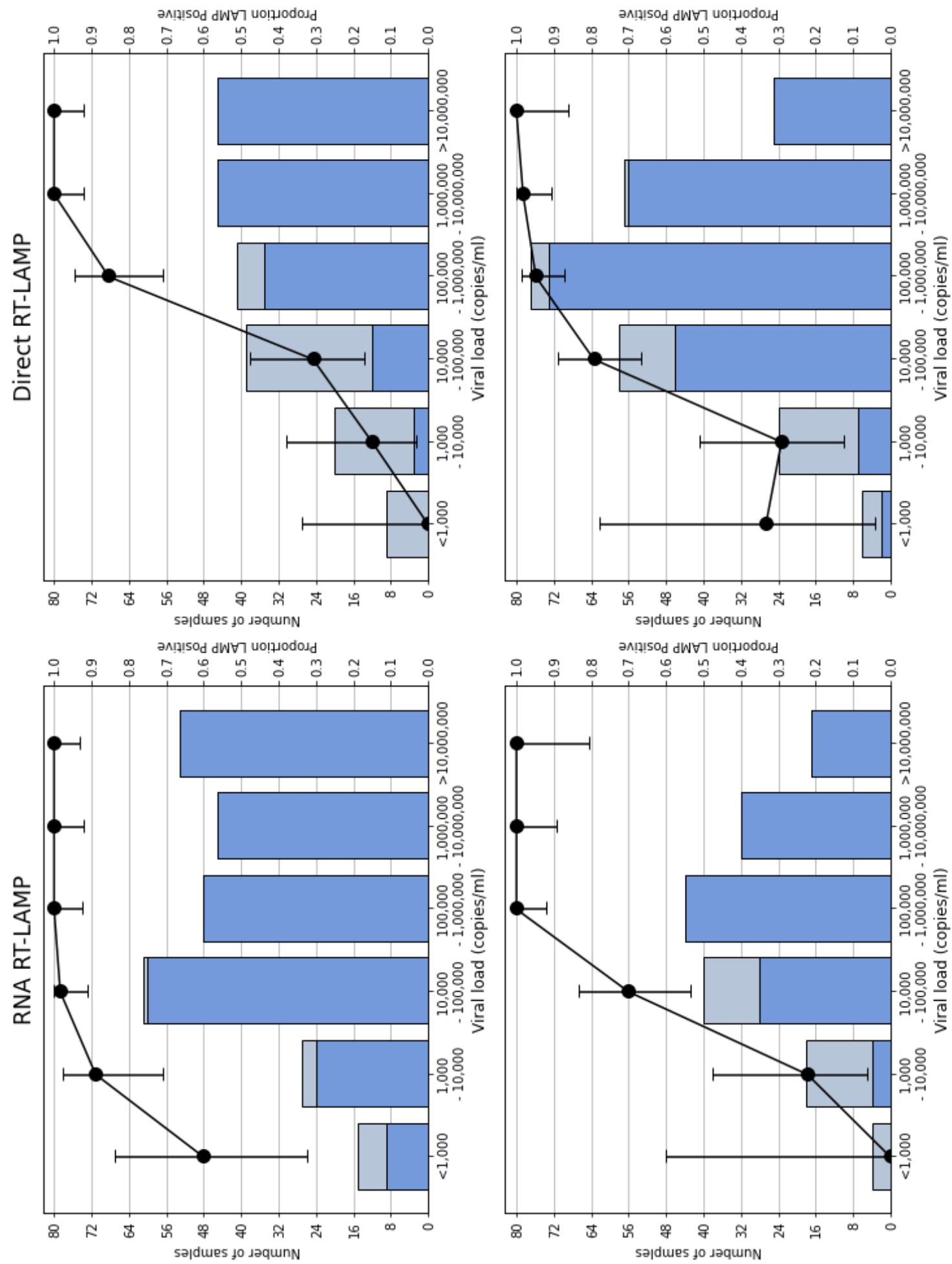

sqems

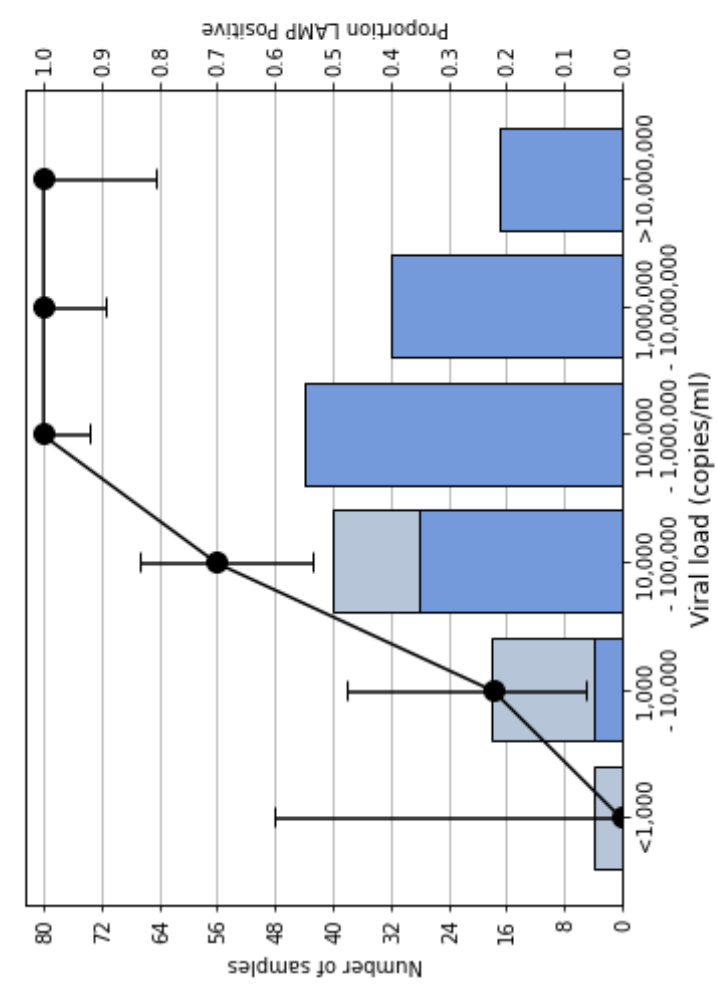

en!jes 
medRxiv preprint doi: https://doi.org/10.1101/2021.06.28.21259398; this version posted January 12, 2022. The copyright holder for this preprint (which was not certified by peer review) is the author/funder, who has granted medRxiv a license to display the preprint in It is made available under a CC-BY-NC-ND 4.0 International license .

Figure 3

\section{Direct RT-LAMP Saliva}

Site

Animal and Plant Health Agency

Hampshire Hospitals NHS Foundation Trust Institute of Cancer \& Genomic Science

Manchester University NHS Foundation Trust Overall

Random effects model
TP FP FN TN Sensitivity $(95 \% \mathrm{Cl})$

Specificity $(95 \% \mathrm{Cl})$

$\begin{array}{llllll}144 & 0 & 12 & 5867 & 0.92[0.87,0.96] & 1.00[1.00,1.00]\end{array}$

$\begin{array}{llllll}42 & 0 & 18 & 527 & 0.70[0.57,0.81] & 1.00[0.99,1.00]\end{array}$

$\begin{array}{llllll}16 & 0 & 0 & 52 & 1.00[0.79,1.00] & 1.00[0.93,1.00]\end{array}$

$\begin{array}{llllll}7 & 0 & 8 & 749 & 0.47[0.21,0.73] & 1.00[1.00,1.00]\end{array}$

$\left.\begin{array}{llllll}209 & 0 & 38 & 7195 & 0.85 & {[0.80,0.89}\end{array}\right] \quad 1.00[1.00,1.00]$

$0.84[0.55,0.96] \quad 1.00[1.00,1.00]$

\section{6}

827

828

829

\section{Direct RT-LAMP Swabs}

Site

Division of Virology, Porton Down

Gibraltar Health Authority

Hampshire Hospitals NHS Foundation Trust

Leeds Teaching Hospitals NHS Trust

Overall

Random effects model
TP FP FN TN Sensitivity $(95 \%$ Cl)

$\begin{array}{lllll}7 & 0 & 12 & 0 & 0.37[0.16,0.62]\end{array}$

$\begin{array}{lllll}31 & 0 & 11 & 11 & 0.74[0.58,0.86]\end{array}$

$\begin{array}{lllll}63 & 0 & 19 & 349 & 0.77\end{array}[0.66,0.85]$

$\begin{array}{lllll}39 & 0 & 17 & 0 & 0.70[0.56,0.81]\end{array}$

$\begin{array}{lllll}140 & 0 & 59 & 360 & 0.70\end{array}[0.63,0.77]$

$0.68[0.54,0.79]$
Specificity $(95 \% \mathrm{Cl})$

Not estimatable

$1.00[0.72,1.00]$

$1.00[0.99,1.00]$

Not estimatable

$1.00[0.99,1.00]$

$1.00[0.99,1.00]$

Sensitivity $(95 \% \mathrm{Cl}) \quad$ Specificity $(95 \% \mathrm{Cl})$

Division of Virology, Porton Down

Gibraltar Health Authority

Hampshire Hospitals NHS Foundation Trust

Leeds Teaching Hospitals NHS Trust

Overall

Random effects model

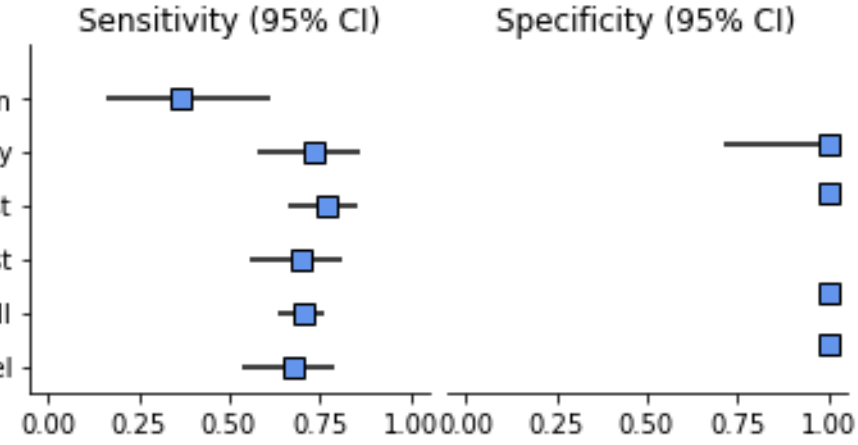


medRxiv preprint doi: https://doi.org/10.1101/2021.06.28.21259398; this version posted January 12, 2022. The copyright holder for this preprint (which was not certified by peer review) is the author/funder, who has granted medRxiv a license to display the preprint in

It is made available under a CC-BY-NC-ND 4.0 International license .

832

Figure 4
833

834

835

836

\section{RNA RT-LAMP Saliva}

Site

Hampshire Hospitals NHS Foundation Trust Institute of Cancer \& Genomic Science

Manchester University NHS Foundation Trust

University Hospital Southampton NHS Foundation Trust

Overall

Random effects model

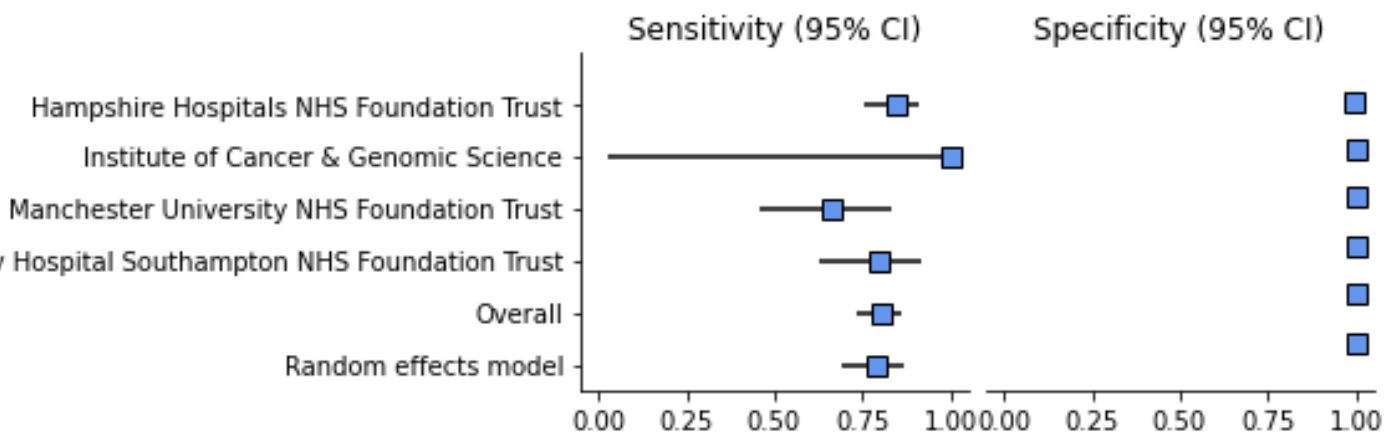

TP FPFN TN Sensitivity $(95 \% \mathrm{Cl}) \quad$ Specificity $(95 \% \mathrm{Cl})$

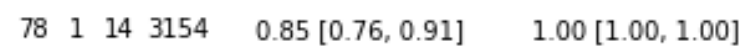

$\begin{array}{llllll}1 & 0 & 0 & 3645 & 1.00[0.03,1.00] & 1.00[1.00,1.00]\end{array}$

$\begin{array}{llllll}18 & 0 & 9 & 2371 & 0.67[0.46,0.83] & 1.00[1.00,1.00]\end{array}$

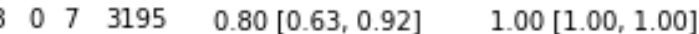

$125130123650.81[0.74,0.87] \quad 1.00[1.00,1.00]$

$0.79[0.69,0.87] \quad 1.00[1.00,1.00]$
University Hospital Southampton NHS Foundation Trust

$\begin{array}{lllllllll}0.00 & 0.25 & 0.50 & 0.75 & 1000.00 & 0.25 & 0.50 & 0.75 & 1.00\end{array}$

\section{RNA RT-LAMP Swabs}

Site

Division of Virology, Porton Down

Hampshire Hospitals NHS Foundation Trust

Institute of Cancer \& Genomic Science

Manchester University NHS Foundation Trust

University Hospital Southampton NHS Foundation Trust

Overall

Random effects model

$\begin{array}{llllll}\text { TP } & \text { FP } & F N & \text { TN } & \text { Sensitivity }(95 \% \mathrm{Cl}) & \text { Specificity }(95 \% \mathrm{Cl}) \\ 19 & 0 & 1 & 0 & 0.95[0.75,1.00] & \text { Not estimatable } \\ 205 & 1 & 8 & 10601 & 0.96[0.93,0.98] & 1.00[1.00,1.00] \\ 0 & 0 & 0 & 1459 & \text { Not estimatable } & 1.00[1.00,1.00] \\ 1 & 0 & 1 & 302 & 0.50[0.01,0.99] & 1.00[0.99,1.00] \\ 14 & 0 & 0 & 2 & 1.00[0.77,1.00] & 1.00[0.16,1.00] \\ 239 & 1 & 10 & 12364 & 0.96[0.93,0.98] & 1.00[1.00,1.00] \\ & & & 0.96[0.93,0.98] & 1.00[1.00,1.00]\end{array}$

TP FPFN TN

(0.93,0.98]
Division of Virology, Porton Down Hampshire Hospitals NHS Foundation Trust Institute of Cancer \& Genomic Science Manchester University NHS Foundation Trust University Hospital Southampton NHS Foundation Trust

Overall Random effects model

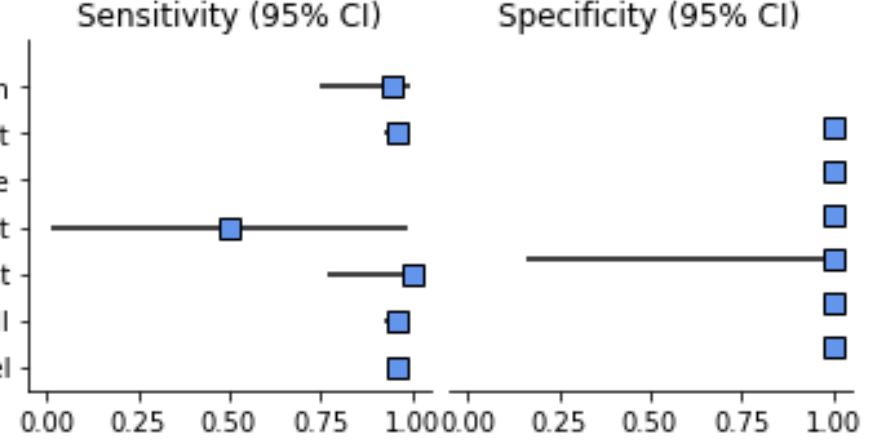


medRxiv preprint doi: https://doi.org/10.1101/2021.06.28.21259398; this version posted January $12,2022$. The copyright holder for this preprint (which was not certified by peer review) is the author/funder, who has granted medRxiv a license to display the preprint in It is made available under a CC-BY-NC-ND 4.0 International license.

Supplemental Information

840

841 Supplemental Table S1: Serial dilution of Patient VTM $\left(C_{T}=19\right) 1: 1$ VTM into Lysis Buffer and $98^{\circ} \mathrm{C}$ heat treatment 842 without and without heat pre-treatment at $56^{\circ} \mathrm{C}$ for 10 or 30 minutes.

\begin{tabular}{|c|c|c|c|c|c|c|c|c|c|c|c|}
\hline $\begin{array}{c}P 07553\left(C_{T}=\right. \\
19)\end{array}$ & $1: 2$ & $1: 4$ & $1: 8$ & 1:16 & $1: 36$ & $1: 64$ & $1: 128$ & $1: 256$ & 1:512 & 1:1024 & $1: 2048$ \\
\hline \multirow{2}{*}{$\begin{array}{l}\text { VTM 1:1 into } \\
\text { Lysis }+98^{\circ} \mathrm{C}\end{array}$} & D & D & D & D & D & D & D & D & D & D & D \\
\hline & D & $D$ & D & D & D & D & D & D & D & D & D \\
\hline \multirow{2}{*}{$\begin{array}{c}56^{\circ} \mathrm{C} 10 \text { mins } \\
\text { pre-treat 1:1 } \\
\text { VTM into lysis } \\
+98^{\circ} \mathrm{C}\end{array}$} & D & D & D & D & D & D & D & D & D & D & ND \\
\hline & D & D & D & D & D & D & D & D & D & D & ND \\
\hline \multirow{2}{*}{$\begin{array}{c}56^{\circ} \mathrm{C} 30 \text { mins } \\
\text { pre-treat } 1: 1 \\
\text { VTM into lysis } \\
+98^{\circ} \mathrm{C}\end{array}$} & D & D & D & D & D & D & D & ND & D & ND & ND \\
\hline & D & D & D & D & D & D & D & D & ND & ND & ND \\
\hline
\end{tabular}

844

845

846

847

Supplemental Table S2 - Serial dilution of Patient VTM ( $C_{T} 19.00$ to 32.08$) 1: 1$ VTM into Lysis Buffer and $98^{\circ} \mathrm{C}$ heat treatment without and without heat pre-treatment at $56^{\circ} \mathrm{C}$ for 10 or 30 minutes.

\begin{tabular}{|c|c|c|c|c|c|}
\hline Patient VTM & $\begin{array}{l}P 07553 \\
\left(C_{T} 19\right)\end{array}$ & $\begin{array}{c}P 01127 \\
\left(C_{T} 23.97\right)\end{array}$ & $\begin{array}{c}P 07102 \\
\left(C_{T} 32.08\right)\end{array}$ & $\begin{array}{c}\text { P07392 } \\
\left(C_{T} 24.55\right)\end{array}$ & $\begin{array}{c}P 01071 \\
\left(C_{T} 20.54\right)\end{array}$ \\
\hline \multirow{2}{*}{ VTM into $1: 1$ Lysis $+98^{\circ} \mathrm{C}$} & $\mathrm{D}$ & $\mathrm{D}$ & $\mathrm{D}$ & $\mathrm{D}$ & $D$ \\
\hline & $\bar{D}$ & $D$ & $D$ & $\mathrm{D}$ & $\mathrm{D}$ \\
\hline \multirow{2}{*}{$\begin{array}{l}56^{\circ} \mathrm{C} 30 \text { mins pre-treat } \\
1: 1 \mathrm{VTM} \text { into lysis }+98^{\circ} \mathrm{C}\end{array}$} & D & D & ND & D & D \\
\hline & $\bar{D}$ & $\bar{D}$ & ND & $\bar{D}$ & $\mathrm{D}$ \\
\hline
\end{tabular}


medRxiv preprint doi: https://doi.org/10.1101/2021.06.28.21259398; this version posted January $12,2022$. The copyright holder for this preprint (which was not certified by peer review) is the author/funder, who has granted medRxiv a license to display the preprint in It is made available under a CC-BY-NC-ND 4.0 International license.

Supplemental Table S3 - Sensitivity of the viral culture assay - 1 PFU/ml

\begin{tabular}{|c|c|c|c|c|c|}
\hline \multirow[b]{2}{*}{$\begin{array}{c}\text { Number of PFU } \\
\text { added to } \\
\text { AVL/flask }\end{array}$} & \multicolumn{3}{|c|}{ E Gene RT-PCR assay } & \multicolumn{2}{|c|}{ Growth (CPE) } \\
\hline & $\begin{array}{l}\mathrm{C}_{\mathrm{T}} \text { value of } \\
\text { dilution } \\
\text { (AVL) }\end{array}$ & $\begin{array}{c}\text { Baseline Mean } \\
\mathrm{C}_{\mathrm{T}} \text { value from } \\
\text { flasks }\end{array}$ & $\begin{array}{l}\text { Final Mean } C_{T} \\
\text { value from } \\
\text { flasks }\end{array}$ & Flask 1 & Flask 2 \\
\hline 1000 & 19.64 & 25.0 & 12.2 & + & + \\
\hline 100 & 22.65 & 28.4 & 11.8 & + & + \\
\hline 10 & 26.00 & 31.8 & 11.9 & + & + \\
\hline 1 & 28.73 & 35.0 & 12.6 & + & + \\
\hline 0.1 & 32.11 & 37.6 & 37.3 & - & - \\
\hline 0.01 & 34.43 & 39.8 & 37.7 & - & - \\
\hline
\end{tabular}

856 Supplemental Table S4 - RT-LAMP results of time course from symptom onset

\begin{tabular}{|c|c|c|c|c|c|c|c|c|c|}
\hline \multirow{2}{*}{$\begin{array}{l}\text { Days post } \\
\text { suspected } \\
\text { exposure }\end{array}$} & \multicolumn{3}{|c|}{ Direct RT-LAMP } & \multicolumn{3}{|c|}{ RNA RT-LAMP } & \multicolumn{2}{|c|}{ RT-qPCR $C_{T}$} & \multirow{2}{*}{ Observed Symptoms } \\
\hline & Tp 1 & $\operatorname{Tp} 2$ & Result & $\operatorname{Tp} 1$ & $\operatorname{Tp} 2$ & Result & ORF1ab & $\mathrm{N}$ & \\
\hline 5 & $09: 18$ & 09:32 & POS & $11: 09$ & $10: 50$ & POS & 23.31 & 26.47 & $\begin{array}{l}\text { Onset: Sore throat. } \\
\text { Blocked nose. } \\
\text { Headache. Lack of } \\
\text { appetite. Fever. }\end{array}$ \\
\hline 6 & $10: 32$ & $11: 34$ & POS & $10: 34$ & $10: 40$ & POS & 21.16 & 24.03 & $\begin{array}{l}\text { Sore throat. } \\
\text { Headache. Restless } \\
\text { sleeping. Tired }\end{array}$ \\
\hline 7 & $10: 19$ & $13: 40$ & POS & $11: 39$ & 09:59 & POS & 24.47 & 27.30 & $\begin{array}{l}\text { Headache. Restless } \\
\text { sleeping. Tired. Loss } \\
\text { of smell and taste. }\end{array}$ \\
\hline 9 & 09:31 & 09:14 & POS & $08: 35$ & 09:37 & POS & 28.55 & 31.89 & $\begin{array}{l}\text { Tired. Loss of smell } \\
\text { and taste. }\end{array}$ \\
\hline 11 & $13: 14$ & $11: 47$ & POS & $16: 44$ & $16: 39$ & POS & 26.44 & 29.06 & $\begin{array}{l}\text { Tired. Loss of smell } \\
\text { and taste. }\end{array}$ \\
\hline 12 & 09:10 & 10:09 & POS & $12: 42$ & $12: 01$ & POS & 26.13 & 29.19 & $\begin{array}{l}\text { Tired. Improvement } \\
\text { in smell and taste. }\end{array}$ \\
\hline 13 & NEG & NEG & NEG & $14: 06$ & $12: 56$ & POS & 28.16 & 30.62 & $\begin{array}{l}\text { Significant } \\
\text { improvement in all } \\
\text { symptoms }\end{array}$ \\
\hline 14 & NEG & NEG & NEG & NEG & NEG & NEG & 38.05 & 40.73 & None \\
\hline 16 & NEG & NEG & NEG & NEG & NEG & NEG & 36.11 & NEG & None \\
\hline 17 & NEG & NEG & NEG & NEG & NEG & NEG & NEG & NEG & None \\
\hline
\end{tabular}

